University of Nebraska - Lincoln

DigitalCommons@University of Nebraska - Lincoln

\title{
Eutrophication and Carbon Sources in Chesapeake Bay Over the Last 2700 Yr: Human Impacts in Context
}

John F. Bratton

U.S. Geological Survey, 384 Woods Hole Rd., Woods Hole, MA 02543, USA

Steven M. Colman

U.S. Geological Survey, 384 Woods Hole Rd., Woods Hole, MA 02543, USA

Robert R. Seal, II

U.S. Geological Survey, 12201 Sunrise Valley Dr., Reston, VA 21092, USA

Follow this and additional works at: https://digitalcommons.unl.edu/usgsstaffpub

Part of the Earth Sciences Commons

Bratton, John F.; Colman, Steven M.; and Seal, II, Robert R., "Eutrophication and Carbon Sources in Chesapeake Bay Over the Last 2700 Yr: Human Impacts in Context" (2003). USGS Staff -- Published Research. 286.

https://digitalcommons.unl.edu/usgsstaffpub/286

This Article is brought to you for free and open access by the US Geological Survey at DigitalCommons@University of Nebraska - Lincoln. It has been accepted for inclusion in USGS Staff -- Published Research by an authorized administrator of DigitalCommons@University of Nebraska - Lincoln. 


\title{
doi:10.1016/S0016-7037(03)00131-5
}

\section{Eutrophication and carbon sources in Chesapeake Bay over the last 2700 yr: Human impacts in context}

\author{
John F. Bratton, ${ }^{1}{ }^{*}$ Steven M. Colman, ${ }^{1}$ and Robert R. Seal, II ${ }^{2}$ \\ ${ }^{1}$ U.S. Geological Survey, 384 Woods Hole Rd., Woods Hole, MA 02543, USA \\ ${ }^{2}$ U.S. Geological Survey, 12201 Sunrise Valley Dr., Reston, VA 21092, USA
}

(Received January 23, 2002; accepted in revised form January 23, 2003)

\begin{abstract}
To compare natural variability and trends in a developed estuary with human-influenced patterns, stable isotope ratios $\left(\delta^{13} \mathrm{C}\right.$ and $\left.\delta^{15} \mathrm{~N}\right)$ were measured in sediments from five piston cores collected in Chesapeake Bay. Mixing of terrestrial and algal carbon sources primarily controls patterns of $\delta^{13} \mathrm{C}_{\text {org }}$ profiles, so this proxy shows changes in estuary productivity and in delivery of terrestrial carbon to the bay. Analyses of $\delta^{15} \mathrm{~N}$ show periods when oxygen depletion allowed intense denitrification and nutrient recycling to develop in the seasonally stratified water column, in addition to recycling taking place in surficial sediments. These conditions produced ${ }^{15} \mathrm{~N}$-enriched (heavy) nitrogen in algal biomass, and ultimately in sediment. A pronounced increasing trend in $\delta^{15} \mathrm{~N}$ of $+4 \%$ started in about A.D. 1750 to 1800 at all core sites, indicating greater eutrophication in the bay and summer oxygen depletion since that time. The timing of the change correlates with the advent of widespread land clearing and tillage in the watershed, and associated increases in erosion and sedimentation. Isotope data show that the region has experienced up to 13 wet-dry cycles in the last $2700 \mathrm{yr}$. Relative sea-level rise and basin infilling have produced a net freshening trend overprinted with cyclic climatic variability. Isotope data also constrain the relative position of the spring productivity maximum in Chesapeake Bay and distinguish local anomalies from sustained changes impacting large regions of the bay. This approach to reconstructing environmental history should be generally applicable to studies of other estuaries and coastal embayments impacted by watershed development. Published by Elsevier Ltd
\end{abstract}

\section{INTRODUCTION}

Chesapeake Bay is the largest estuary in North America and among the most productive in the world. Mean summer productivity in the mesohaline Chesapeake can exceed $4 \mathrm{~g} \mathrm{C} \mathrm{m}^{-2}$ $\mathrm{d}^{-1}$ (Malone, 1991). Average spring rates of carbon deposition calculated from chlorophyll-a measurements of sediment trap material range from 0.1 to $1.3 \mathrm{~g} \mathrm{C} \mathrm{m}^{-2} \mathrm{~d}^{-1}$, representing 40 to $60 \%$ of total annual primary productivity (Boynton et al., 1993). The average depth of the bay is $8 \mathrm{~m}$ but an axial channel, a remnant of the glacial lowstand valley of the Susquehanna River, runs down the center of the bay reaching depths of up to $54 \mathrm{~m}$ (Fig. 1). The estuary is well mixed during the winter months, but typically becomes stratified from May though September. A pycnocline develops at a depth of 10 to $15 \mathrm{~m}$, just below the break in slope at the edge of the axial channel.

Officer et al. (1984) demonstrated that summer oxygen depletion in Chesapeake Bay was a result of stratification and subpycnocline respiration of organic matter. Officer et al. (1984) were also among the first to identify a multi-decadal trend of increasing oxygen depletion (quantified as volume of water with $<0.5 \mathrm{~mL} \mathrm{~L}^{-1} \mathrm{O}_{2}$ ) in Chesapeake subpycnocline waters. They warned of possible widespread mortality of benthic organisms, including oysters and crabs, if the trend continued (but see also Seliger et al., 1985).

Intense monitoring since the early 1980s has shown that during a typical summer, low dissolved oxygen conditions $(<3$ $\mathrm{mg} \mathrm{L}^{-1}$ ) develop in 15 to $20 \%$ of the total volume of Chesapeake Bay (11-15 km $\mathrm{km}^{3}$ of low-oxygen water). Most interannual

* Author to whom correspondence should be addressed (jbratton@usgs.gov). variability in summer oxygen depletion is correlated with variation in river discharge from December through March (Boynton et al., 1993), especially variation in discharge from the Susquehanna River that typically accounts for $60 \%$ of the total freshwater input to Chesapeake Bay. Higher spring discharge delivers more nutrients to the bay, producing more biomass in spring algal blooms. As this biomass sinks, it decomposes and consumes oxygen that cannot be replaced due to water-column stratification during the spring and summer.

It has been generally assumed that eutrophication caused by human activities has played a significant role in the development and increasing severity of summer oxygen depletion in the Chesapeake (e.g., Cooper and Brush, 1991). Increased nutrient delivery related to agricultural development of the watershed and wastewater disposal practices is believed to have caused greater production of algal biomass in the estuary, which in turn has fueled oxygen depletion through decomposition. The relative importance of natural variability and climatic control of the system, however, has not been well constrained. Regular and systematic measurement of water quality indicators in the bay only began in the 1950 s, so longer-term trends in nutrient loading, algal blooms, and dissolved oxygen are unknown. Many studies have quantified processes related to oxygen depletion in the modern Chesapeake Bay including Boynton et al. (1993, 1995), Kemp et al. (1990, 1992), and Cowan and Boynton (1996).

While depletion of oxygen in the modern water column was being investigated, parallel efforts began to explore its historical context. This was done using long-term data sets and examination of pollen, diatoms, and geochemistry in short sediment cores (Brush, 1984; Cooper and Brush, 1991, 1993; Cooper, 1995; Harding and Perry, 1997). Sediment core results 

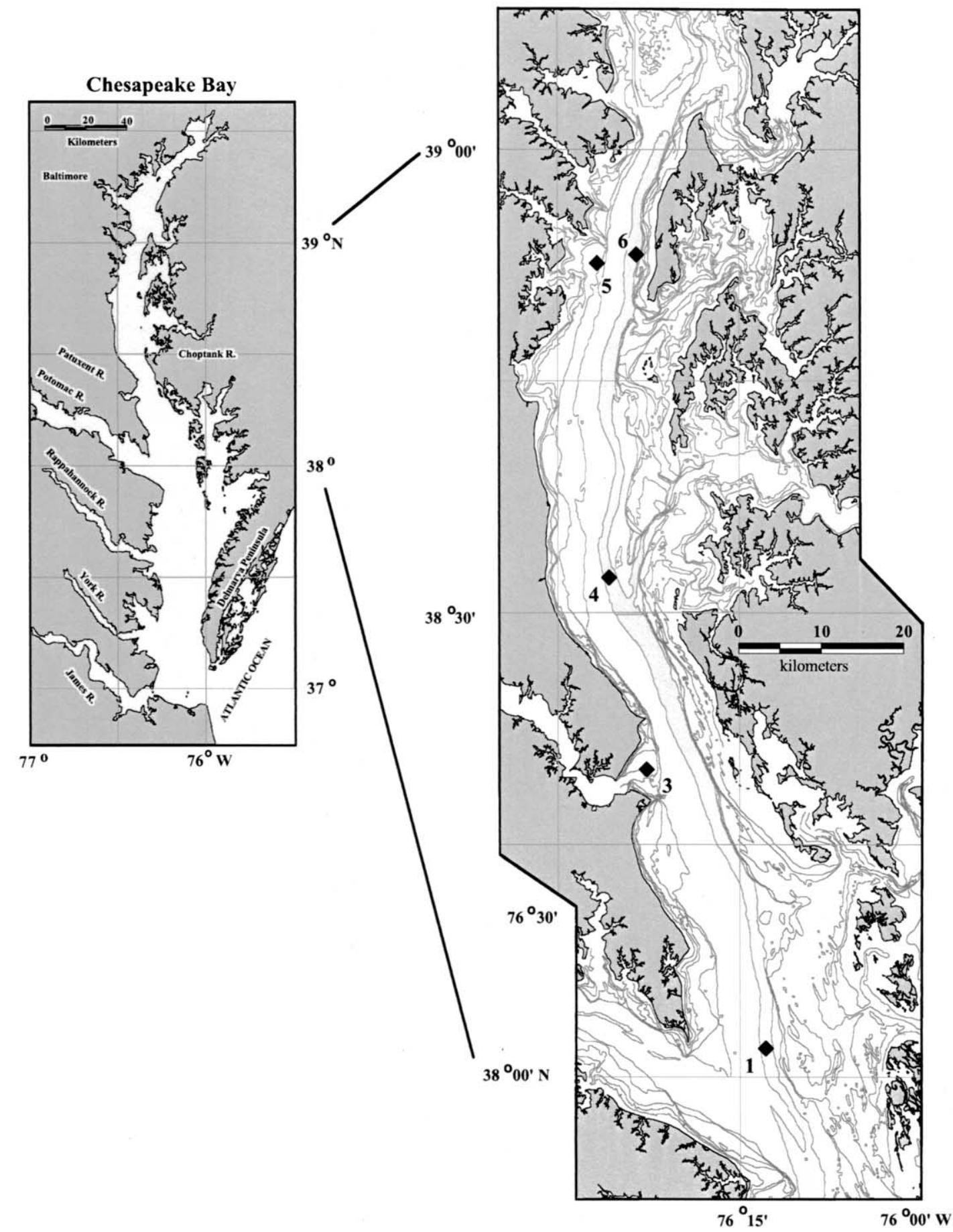

Fig. 1. Map showing Chesapeake Bay bathymetry and locations of sediment coring sites. Bathymetric contours are in feet $(6,12,18,30,36$, and $60 \mathrm{ft} ; 1.8,3.7,5.5,9.1,11.0$, and $18.3 \mathrm{~m}$, respectively); area of deep axial basin is bounded by the $60-\mathrm{ft}(18.3-\mathrm{m})$ contour line. Bathymetric data are from NOAA. Data from site 2 (number not shown on figure) are not included in this discussion but the numbering system is maintained for consistency with Colman et al. (2002).

suggested an overall increase in eutrophication and sedimentation rates in Chesapeake Bay over the last few centuries. These changes were attributed to land clearing following colonization and the resulting erosion of soils and delivery of associated nutrients to the bay. Cornwell et al. (1996) studied carbon, nitrogen, phosphorus, and biogenic silica in two cores with a record spanning the last century. Their results indicated that separating effects of sediment diagenesis from eutrophication signals was not straightforward. Miller (1992) and Adelson et al. (2001) examined cores using redox-sensitive metals as oxygen depletion proxies with mixed results, but they concluded "Chesapeake Bay has experienced growing $\mathrm{O}_{2}$ depletion since 
Table 1. Descriptions of core locations and related details.

\begin{tabular}{|c|c|c|c|c|c|c|c|c|}
\hline $\begin{array}{c}\text { Site } \\
\text { number }\end{array}$ & Core name & Coring date & Location & $\begin{array}{c}\text { Water } \\
\text { depth }(\mathrm{m})\end{array}$ & Corer type & $\begin{array}{c}\text { Latitude } \\
(\text { degrees } \mathrm{N})\end{array}$ & $\begin{array}{l}\text { Longitude } \\
\text { (degrees W) }\end{array}$ & $\begin{array}{l}\text { Length } \\
(\mathrm{cm})\end{array}$ \\
\hline 1 & PTMC-3-1 & 25 Sep 96 & Deep channel near Potomac River & 23.1 & Long piston & 38.0278 & 76.2203 & 404 \\
\hline 3 & PX98-2 & 16 Jun 98 & Patuxent River mouth & 8.7 & Long piston & 38.3311 & 76.3781 & 457 \\
\hline 4 & PRCK-3-2 & 9 Oct 96 & Deep channel off Parker Creek & 24.3 & Long piston & 38.5439 & 76.4282 & 452 \\
\hline 5 & RR98-6 & 15 Jun 98 & Mainstem off Rhode River & 7.9 & Long piston & 38.8776 & 76.4456 & 413 \\
\hline 6 & RD98-P2 & 12 Nov 98 & Deep channel off Rhode River & 26.5 & Long piston & 38.8867 & 76.3917 & 459 \\
\hline
\end{tabular}

the first half of the 20th century, but especially after 1960." Zimmerman and Canuel $(2000,2002)$ measured organic biomarkers in cores from the mesohaline (5-20\%o salinity) Chesapeake and showed overall trends of increasing productivity, and specific trends of increasing importance of bacteria and dinoflagellates relative to diatoms in the bay since the early 1900s. They also duplicated stable isotope analyses on parts of two cores discussed here. Cronin et al. (2000) reported benthic microfossil evidence linking Chesapeake salinity over the last $550 \mathrm{yr}$ with droughts and wet periods recorded in cypress tree rings (Stahle et al., 1998).

Most previous studies of stable isotopes of carbon and nitrogen in Chesapeake Bay and nearby Delaware Bay have been limited to samples from the water column and surface sediments (Hunt, 1966; Sigleo and Macko, 1985; Cifuentes et al., 1988; Montoya et al., 1990, 1991; Fogel et al., 1992). These investigations have been critical to developing an understanding of the modern system, but they have not explored the longer time record. Understanding how the biogeochemistry of the Chesapeake has evolved in response to Holocene sea-level rise, climate change, and human modification of the watershed is critical to determining the best practices for management of this system and other developed estuaries.

The study described here examines carbon and nitrogen isotopes from sediments deposited in northern Chesapeake Bay over the last $2700 \mathrm{yr}$. These data allow human-induced changes to the ecosystem to be put in a sufficiently long predisturbance context to reveal natural extremes and cycles of variability, as well as trends lasting longer than $300 \mathrm{yr}$. In addition, they provide time-averaged baseline information that can be integrated with modern monitoring programs to detect expected recovery of the system as nutrient loading is reduced.

\section{METHODS}

Sediment cores were collected in 1996 and 1998 at the locations and depths shown in Figure 1 and in Table 1. Cores were collected from the $R / V$ Discovery with a piston corer capable of penetrating and recovering up to $4.5 \mathrm{~m}$ of sediment. Coring operations and the physical properties of the sediments are described in more detail by Kerhin et al. (1998), Cronin et al. (2000), and Baucom et al. (2001). Cores were collected in 1.5-m lengths of polycarbonate liner that were immediately capped after being removed from the piston corer. Sediments consisted of dark gray to black estuarine silty clay with varying amounts of fine sand and shells (especially shells of the opportunistic bivalve Mulinia lateralis). Cores from shallow-water locations above the seasonal pycnocline were coarser grained (up to $\sim 15 \%$ fine sand and up to $90 \%$ silt) and more bioturbated than cores from the deep axial channel. Water content of sediment was consistently 50 to $70 \mathrm{wt} . \%$. The upper portions of some cores were color-banded; X-ray images showed laminations throughout indicating a lack of bioturbation.

Refrigerated cores were split lengthwise and bulk-sampled in either
2- or 3-cm slices. Subsamples for geochemical analysis were either collected from discrete depths immediately before bulk sampling, or were split later from bulk samples. Spacing of analyzed samples was between 3 and $10 \mathrm{~cm}$, but was consistent within each core. Samples were dried at $60^{\circ} \mathrm{C}$ and crushed with a mortar and pestle. Subsamples for carbon and nitrogen isotope analyses were acidified with $10 \% \mathrm{HCl}$ to remove any carbonate, dried again, and homogenized. Nitrogen isotope analyses of five pairs of acidified and non-acidified subsamples selected at random showed no statistically significant difference between them. Tests of benthic foraminifera were picked from uncrushed and unacidified sample splits from two cores.

Carbon and nitrogen, bulk and isotopic compositions were determined using a Carlo Erba NC2500 elemental analyzer coupled to a Finnigan Delta Plus isotope ratio mass spectrometer at the USGS facilities in Reston, Virginia. Total organic carbon (TOC) and total nitrogen (TN) determinations were calibrated using a marine sediment standard, the National Research Council of Canada Certified Reference Material PACS-2, with values of 3.32 mass percent $\mathrm{C}$ and 0.27 mass percent $\mathrm{N}$. Carbon isotope compositions were measured on $\mathrm{CO}_{2}$ and are reported in the $\delta$-notation, as permil $(\%$ ) relative to Vienna-Pee Dee belemnite (VPDB). The $\delta^{13} \mathrm{C}$ values are calibrated on a scale defined by USGS-24 (graphite) with $\delta^{13} \mathrm{C}=-15.9 \%$. Analytical precision is estimated to be $\pm 0.2 \%$ o $(1 \sigma)$. Nitrogen isotope compositions were made on $\mathrm{N}_{2}$ and are reported in the $\delta$-notation, as permil (\%o) relative to atmospheric $\mathrm{N}_{2}$. The ${ }^{15} \mathrm{~N}$ values are calibrated on a scale defined by an internal laboratory reference material G-3646 (acetanilide) with $\delta^{15} \mathrm{~N}=-1.7 \pm 0.1 \%$, which in turn, is referenced to a scale defined by IAEA-N1 (ammonium sulfate) with $\delta^{15} \mathrm{~N}=0.43 \%$ and USGS-32 (potassium nitrate) with $\delta^{15} \mathrm{~N}=180 \%$. Analytical precision is estimated to be $\pm 0.2 \%$ \% $(1 \sigma)$.

Carbonate $\delta^{13} \mathrm{C}$ of foraminifera from two cores (sites 1 and 4) was determined by reacting one to three individual tests from each productive interval in a Kiel device and measuring isotope ratios of evolved $\mathrm{CO}_{2}$ with a Finnigan MAT252 mass spectrometer operated by the Paleoceanography Research Group at the Woods Hole Oceanographic Institution. Results are reported relative to the Pee Dee belemnite standard (PDB). Calibration and precision of this instrument are described in Ostermann and Curry (2000).

Exceptional geochronological resolution, as detailed in Colman et al. (2002), was developed for these core sites using a suite of complementary techniques including multi-fraction radiocarbon analysis of $>70$ samples, pollen stratigraphy, ${ }^{210} \mathrm{~Pb}$ and ${ }^{137} \mathrm{Cs}$ measurements, and paleomagnetic correlation. Age uncertainty is $\sim \pm 50$ to $200 \mathrm{yr}$ in the older part of the record, and \pm 5 to $40 \mathrm{yr}$ in the last few centuries. Comparison of rates of accumulation among sites indicates large spatial variability of sedimentation rates in the bay, especially in relatively shallow-water environments. Shallow sites examined typically have lower sedimentation rates than deep sites. Modern rates for all sites range from 0.05 to $1.8 \mathrm{~cm} \mathrm{yr}^{-1}$ at sites 4 and 6, respectively. Deepwater, axial-channel sites 1 and 6 differ in modern rates of accumulation by a factor of 2 . The same two sites show increases of 3.6 and 4.2 times, respectively, in the last 200 to $300 \mathrm{yr}$, attributed to erosion associated with increases in agriculture and land clearing in the watershed following colonization. To avoid areas of the modern Chesapeake Bay floor that are erosional, core sites that contained $>5 \mathrm{~m}$ of Holocene sediment were selected using geophysical survey data. 

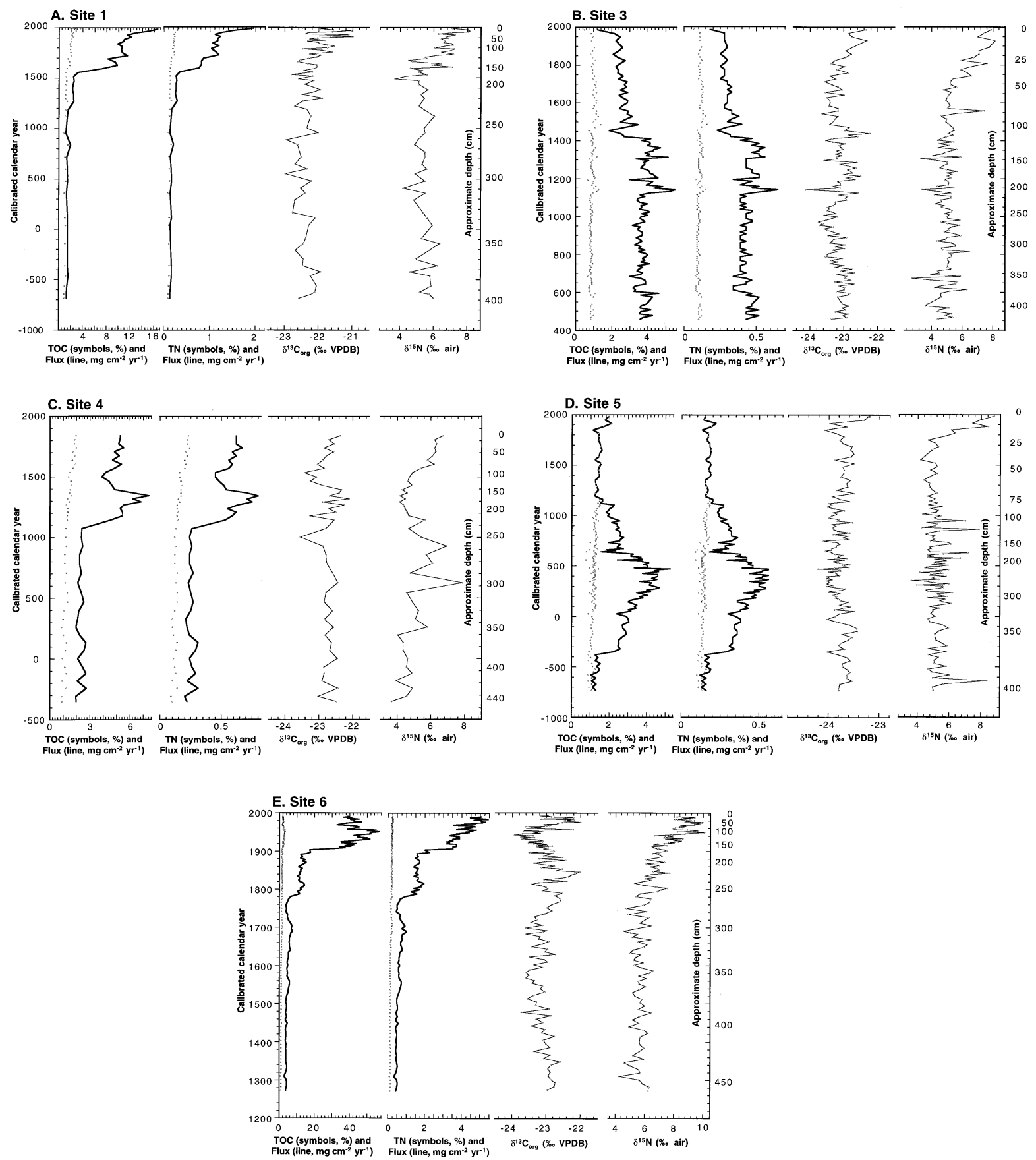

Fig. 2. Plots of sediment TOC and flux, TN and flux, $\delta^{13} \mathrm{C}_{\mathrm{org}}$, and $\delta^{15} \mathrm{~N}$ vs. calendar year and depth for cores from (A) site 1, (B) site 3, (C) site 4, (D) site 5, and (E) site 6. Calendar years are A.D. (negative values = B.C.). Depth scales on right $\mathrm{y}$-axes are non-linear.

\section{RESULTS}

\subsection{Nitrogen}

Total nitrogen and $\delta^{15} \mathrm{~N}$ profiles for the five cores analyzed are shown in Figure 2. Values of TN for deep-water cores (sites 1,4 and 6) decrease from 0.23 to $0.33 \%$ near the core tops to 0.10 to $0.12 \%$ near the bottoms of the cores, equivalent to a relative downcore decrease of 50 to $70 \%$. There is a slight decreasing oceanward trend in core-top and average $\mathrm{TN}$ values among deep-water cores. Shallow-water values (sites 3 and 5) are lower $(0.11-0.19 \%)$ in the core tops than deep-water values and decrease by $<25 \%$ downcore. The $\mathrm{TN}$ values for these two cores indicate the possibility of a decreasing oceanward trend in $\mathrm{TN}$ of surface sediments deposited in relatively shallow water $(<10 \mathrm{~m})$, although the location of the shallow sites adjacent to tributaries of much different sizes may bias these results. Superimposed on the general downcore TN trends are several features of shorter duration. 
Fluxes of TN (Fig. 2) range from 0.1 to $5.5 \mathrm{mg} \mathrm{cm}^{-2} \mathrm{yr}^{-1}$ across all cores and depths. As with TN values, TN fluxes are highest in the upper parts of the deep-water cores (sites 1, 4, and 6). The fluxes peak in the middle of the shallow-water cores (A.D. 1350 at site 3 and A.D. 400 at site 5), with fluxes decreasing toward the core tops. Because flux calculations are a function of sedimentation rates and diagenesis, it is probably more appropriate to consider the rates calculated for these cores as burial or preservation rates rather than true fluxes from the water column to sediment. Stated another way, this means that the different modern fluxes at site 5 vs. site $6(0.15 \mathrm{vs} .5 .0 \mathrm{mg}$ $\left.\mathrm{cm}^{-2} \mathrm{yr}^{-1}\right)$, for example, probably do not indicate a true 33 -fold difference in TN fluxes at the two sites. Rather, the rapid sedimentation rate and summer anoxia at site 6 preserve more of the TN that reaches the sediment surface at this site than at site 5 .

Like TN results, $\delta^{15} \mathrm{~N}$ profiles (Fig. 2) show consistent patterns when the cores are grouped by water depth. Measurements in cores from sites 3 and 5 collected above the seasonal pycnocline decrease from $\sim 8 \%$ at the tops of the cores to $5 \%$ o at sediment depths of $50 \mathrm{~cm}$. Average values remain at $\sim 5 \%$ o to the bottoms of the cores. Values of $\delta^{15} \mathrm{~N}$ from the tops of deep-water cores (sites 1, 4, and 6) start near the shallow-water range $(8 \pm 1.5 \%$ ) but decrease more gradually than in shallowwater cores due to higher sedimentation rates. There is no discernible oceanward trend in $\delta^{15} \mathrm{~N}$ data in either shallowwater or deep-water cores.

\subsection{Carbon}

TOC in sediments and $\delta^{13} \mathrm{C}_{\text {org }}$ profiles for the five cores sampled are shown in Figure 2. Cores generally show a decrease in TOC in the top 1 to $3 \mathrm{~m}$ that stabilizes at $\sim 0.75$ to $1.2 \%$. Modern net fluxes of TOC to sediment based on postA.D. 1800 sedimentation rates (Colman et al., 2002), and maximum TOC concentrations in the upper parts of each core (Fig. 2) range from 0.001 (site 4) to $0.05 \mathrm{~g} \mathrm{~cm}^{-2} \mathrm{yr}^{-1}$ (site 6). TOC and TN are highly correlated (Figs. 2 and 3) with an average $\mathrm{C} / \mathrm{N}$ of $8.8: 1$. The correlation is especially clear in cores from sites 1, 3, and 4 (Figs. 2A-2C). On average, TOC decreases slightly from north to south and from deep to shallow water. Trends of $\mathrm{C} / \mathrm{N}$ increase slightly from north to south and from shallow to deep water. An anomalous enrichment of TOC relative to TN in the core from site 6 between $\sim 1910$ and 1960 $(50-150 \mathrm{~cm})$ is discussed further below.

Fluxes of TOC (Fig. 2) range from 1.0 to $58 \mathrm{mg} \mathrm{cm}^{-2} \mathrm{yr}^{-1}$ across all cores and depths. As with TN, TOC fluxes are highest in the upper parts of the deep-water cores (sites 1, 4, and 6) indicating an increase of as much as 30 -fold over rates calculated for the oldest sediments. The flux patterns generally mirror TN fluxes in all cores, except at site 6 where TN fluxes rose steadily over the last century but TOC fluxes peaked at $\sim 1950$ and have declined since then. As with TN, fluxes of TOC calculated from cores incorporate preservational biases due to variations in sedimentation rate and oxygen availability, and should be considered minimum values for the true TOC rain rate at the sediment surface. A sediment trap study would be required to better quantify true fluxes. Boynton et al. (1993) performed such a study from 1985 to 1992 and measured particulate carbon deposition rates at middepths that averaged
11 to $62 \mathrm{mg} \mathrm{cm}^{-2} \mathrm{yr}^{-1}$. This range agrees well with the modern core-derived rates calculated for sites 1 and 6 (Fig. 2), but is much higher than the rates estimated from shallow-water cores.

At both shallow and deep-water core sites, there is an oceanward trend toward heavier (less negative) $\delta^{13} \mathrm{C}_{\text {org }}$ values, consistent with Hunt (1966). The average values for the northernmost cores (site $6,-23.0 \%$; site $5,-23.7 \%$ ) are 0.9 to $1.6 \%$ o lighter than for the southernmost core (site $1,-22.1 \%$ ). There is also a shallow-water to deep-water gradient of increasing $\delta^{13} \mathrm{C}_{\text {org }}$ values. For example, the average $\delta^{13} \mathrm{C}_{\text {org }}$ of the core from deep-water site 6 is $0.7 \%$ o heavier than the value from the nearby shallow-water site 5 . The within-core variation from average $\delta^{13} \mathrm{C}_{\text {org }}$ values is $\sim \pm 0.7 \%$ o for deep-water cores and $\pm 0.4 \%$ or for shallow-water cores. A slight downcore decrease of $<0.7 \%$ in $\delta^{13} \mathrm{C}_{\text {org }}$ is apparent at some sites; possible explanations are discussed below.

\section{DISCUSSION}

Here we interpret the Chesapeake Bay data described above with respect to changes in carbon sources in sediment, freshening of the bay, eutrophication and oxygen depletion, correlation among cores and with other data sets, paleoclimatic context, and application of these approaches to other estuaries.

\subsection{Changing Carbon Sources Based on $\mathrm{C} / \mathrm{N}$ and $\delta^{13} \mathrm{C}_{\text {org }}$}

Measurements of $\delta^{13} \mathrm{C}_{\text {org }}$ and $\mathrm{C} / \mathrm{N}$ can be used to interpret long-term and large-scale patterns of changes in carbon sources in bay sediments. Sedimentary $\delta^{13} \mathrm{C}_{\text {org }}$ is likely to be influenced by five factors: (1) mixing of marine and terrestrial particulate organic carbon (POC) as described above, (2) $\mathrm{HCO}_{3}{ }^{-}$assimilation by phytoplankton resulting from dissolved $\mathrm{CO}_{2}$ limitation caused by high productivity $\left(\delta^{13} \mathrm{C}_{\mathrm{org}}\right.$ values would become more positive; e.g., Fogel et al., 1992), (3) shifting of terrestrial carbon supply from $\mathrm{C}_{3}$ plants (trees and shrubs, lighter $\delta^{13} \mathrm{C}_{\text {org }}$ ) to $\mathrm{C}_{4}$ plants (grasses, corn, and some other agricultural plants; e.g., Goñi et al., 1997), (4) changes in input of salt marsh vegetation and seagrass (heavy $\delta^{13} \mathrm{C}_{\mathrm{org}} \approx-7$ to $-13 \%$; McMillan et al., 1980, Haddad and Martens, 1987), and (5) postdepositional diagenesis (Cornwell et al., 1996).

Factor 1 , mixing of terrestrial and marine $\delta^{13} \mathrm{C}_{\text {org }}$ end members ( $\sim-26$ and $-20 \%$ o, respectively), would produce a trend of increasing $\delta^{13} \mathrm{C}_{\text {org }}$ values with increasing distance from the head of the bay. The sediment and particulate matter data sets plotted in Figure 4A and listed in Table 2 show the expected trend, especially the data of Hunt (1966), indicating that mixing of sources dominates the $\delta^{13} \mathrm{C}_{\text {org }}$ signal in cores. Trends of core averages are similar if shallow-water and deep-water cores are considered separately (Fig. 4A). Deviations from a conservative mixing model based on salinity (factor 1, Fig. 4A; model approximately equals the curve of Hunt's [1966] data) in Chesapeake Bay data are mostly positive (higher $\delta^{13} \mathrm{C}_{\mathrm{org}}$ than expected based on the position in the bay). This is consistent with the influence of factor 2,3 , or 4 above. Factor $2\left(\mathrm{CO}_{2}\right.$ limitation) has been suggested as an explanation of transient watercolumn $\delta^{13} \mathrm{C}_{\text {org }}$ values in POC as heavy as $-17 \%$ in Delaware Bay (Fogel et al., 1992). Limitation of $\mathrm{CO}_{2}$ availability is most likely to take place under high-productivity conditions so this 


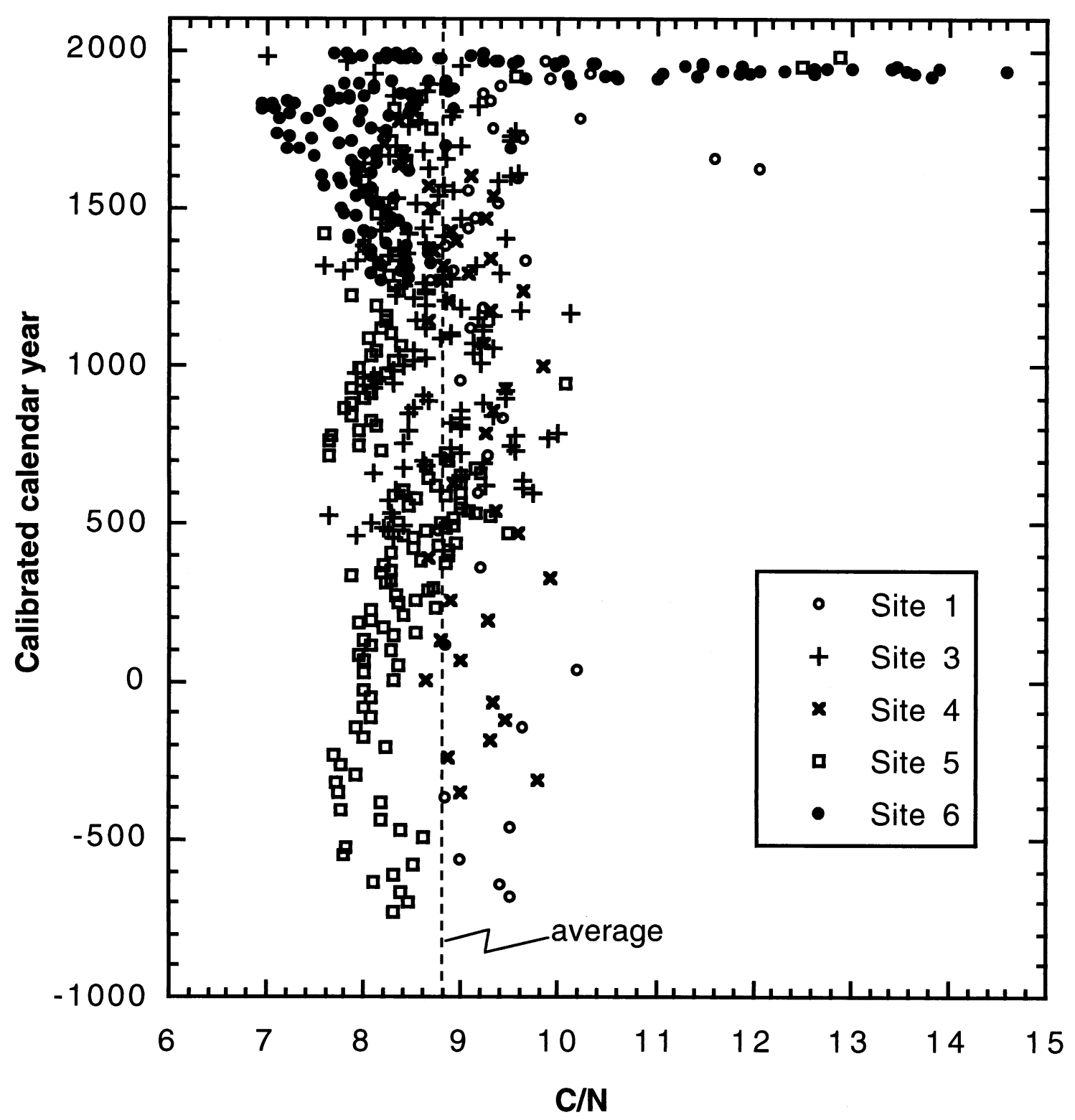

Fig. 3. $\mathrm{C} / \mathrm{N}$ ratios vs. calendar year for all cores with core-specific symbols as indicated. The line shown (8.8:1) is the average $\mathrm{C} / \mathrm{N}$ ratio for all data from the five cores. Average ratios for each core follow: site 1, 9.5; site 3, 8.7; site 4, 9.0; site $5,8.4$; and site $6,8.9$.

factor would grow in importance as eutrophication increased. Values as high as those reported for mixed terrestrial and algal POC in the water column $(-17 \%$ o), however, are not observed in Delaware Bay (or Chesapeake Bay) surface sediments or cores, so time-averaging of the signal and early diagenesis appear to curtail the full influence of these transient extreme conditions (Fogel et al., 1992; McArthur et al., 1992).

Factor $3\left(\mathrm{C}_{3}\right.$ to $\mathrm{C}_{4}$ vegetation change) may become important in Chesapeake Bay on a millennial time scale, but it is not clear how much terrestrial carbon in modern and recent bay sediments is derived from young ( $<300 \mathrm{yr}$ old) vegetation vs. old soil carbon. In the Gulf of Mexico, Goñi et al. (1997) discussed the importance of taking this $\mathrm{C}_{3}$ to $\mathrm{C}_{4}$ mechanism into account for understanding carbon isotope changes in glacial to Holo- cene sediments that incorporated terrestrial organic matter from the Great Plains. Radiocarbon ages for bulk sediment TOC from Chesapeake Bay are consistently $>1500 \mathrm{yr}$ older than shell carbonate from the same horizons, indicating that old soil carbon may contribute the bulk of terrestrial organic matter in these sediments (Colman et al., 2002). Therefore, transition to $\mathrm{C}_{4}$ agricultural plants in the watershed within the last $300 \mathrm{yr}$ should not yet have significantly impacted $\delta^{13} \mathrm{C}_{\text {org }}$ of sediments.

Factor 4 (salt marsh vegetation and seagrass) is likely to be an important influence on $\delta^{13} \mathrm{C}_{\text {org }}$ of POC only in the immediate vicinity of salt marshes and seagrass beds due to the large size, small tidal range, and great algal productivity of Chesapeake Bay. Stribling and Cornwell (1997) measured $\delta^{13} \mathrm{C}_{\text {org }}$ 


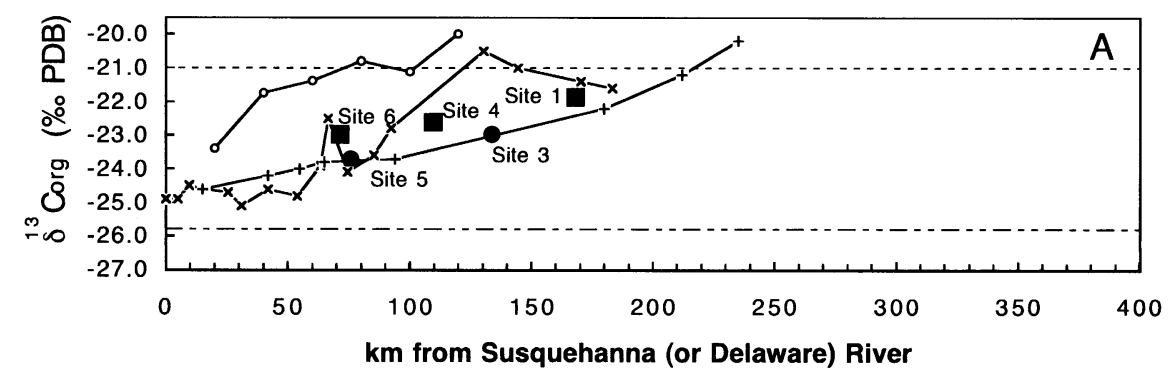

Deep-water core averages (since 1700 A.D.)

- Shallow-water core averages (since 1700 A.D.)

$\longrightarrow \mathbf{x}$ - Surface sediments (E. Spiker, written communication)

- - Hunt, 1970

- - - Sigleo and Macko (1985) particulate, Patuxent R. (upper limit)

-..- Sigleo and Macko (1985) particulate, Patuxent R. (lower limit)

- Cifuentes et al. (1988), surface sediments in Delaware Bay

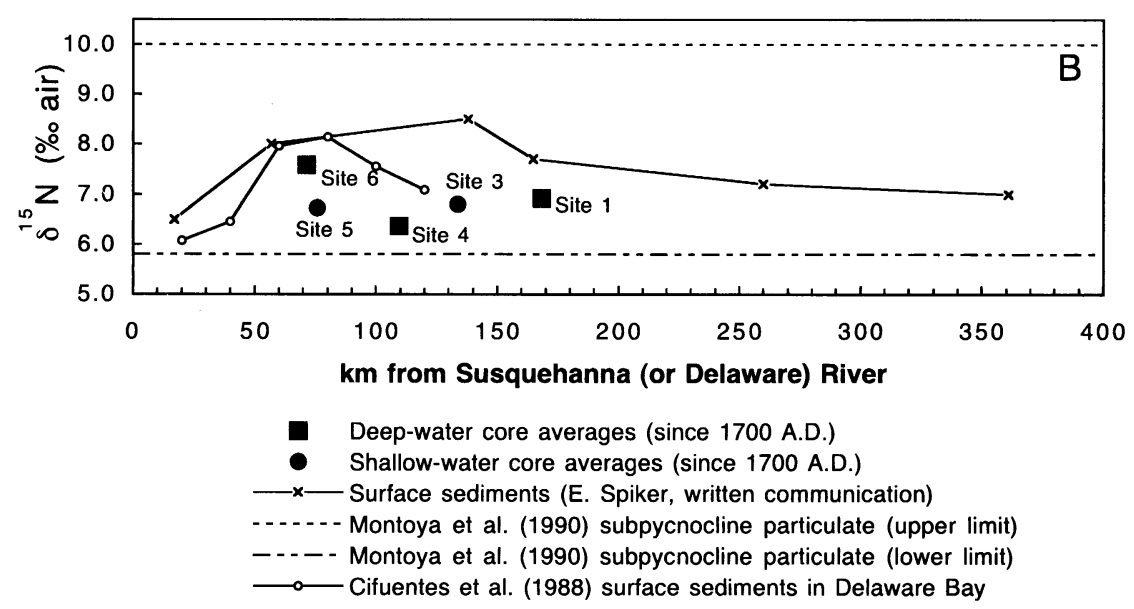

Fig. 4. Values of (A) $\delta^{13} \mathrm{C}_{\text {org }}$ and (B) $\delta^{15} \mathrm{~N}$ for transects or ranges of surface sediment samples or particulate matter from Chesapeake Bay, the Patuxent River subestuary (a Chesapeake Bay tributary, see Fig. 1), and Delaware Bay (next major estuary north of Chesapeake Bay on the Atlantic coast of the U.S.). Core site average values since A.D. 1700 are also shown and labeled for comparison. Note that the average site $4 \delta^{15} \mathrm{~N}$ value is lower than other deepwater core values (sites 1 and 6) because sediments $<\sim 160 \mathrm{yr}$ old were not recovered at that site.

values of sediment samples collected within a tidal creek in a Chesapeake Bay salt marsh and found none heavier than $-19.2 \%$. This indicates that the heavy isotopic signature of salt marsh vegetation, and probably seagrass as well, is rapidly obscured in offshore sediments by other carbon sources. The lower average $\delta^{13} \mathrm{C}_{\text {org }}$ values in shallow-water Chesapeake cores compared with deep cores (Fig. 4A) are also inconsistent with this factor playing an important role in the $\delta^{13} \mathrm{C}_{\text {org }}$ of the larger system. Factor 5 (diagenesis) will be discussed further below.

Early diagenetic overprints (Factor 5) must be distinguished from anthropogenic signals in cores before meaningful interpretations can be made. In particular, natural downcore degradation of organic matter must be separated from the effects of recent eutrophication and increased productivity (Cornwell et al., 1996). Minimal impact of aerobic diagenesis is evidenced by laminations and banding in the site 6 core, which indicate a lack of bioturbation and probable deposition under bottom waters that were consistently depleted of oxygen from late spring through early fall (Officer et al., 1984); shallow-water sites ( 3 and 5 ) should be more heavily impacted by diagenesis due to aerobic conditions. Boehme et al. (1996) and Lehmann et al. (2002) demonstrated that anoxic diagenesis only alters the $\delta^{13} \mathrm{C}_{\text {org }}$ composition of residual organic carbon in sediment by 0 to $-1.7 \%$. The small downcore variability of $\delta^{13} \mathrm{C}_{\text {org }}$ in all cores (total range $<2 \%$ in any core) indicates that diagenesis has only a small effect on values.

Based on consideration of the above possible influences on $\delta^{13} \mathrm{C}_{\text {org }}$ in sediment, the core from site 6 probably contains the best record of Chesapeake Bay carbon cycling of the five sites sampled for the last several centuries. The core site is located $\sim 45 \mathrm{~km}$ south of the modern turbidity maximum of the estuary (Schubel, 1968) in an area of dense spring diatom blooms and extreme summer oxygen depletion. Marine POC is mostly produced by algae and has a value of $\delta^{13} \mathrm{C}_{\text {org }}$ of $\sim-20 \%$ (see downstream data of Hunt, 1966, shown in Fig. 4A, also compilation of Hofmann et al., 2000). Fluvial POC, such as that carried by the Susquehanna River, tends to be isotopically 
Table 2. Surficial sediment and published water column isotope data from Chesapeake Bay and Delaware Bay.

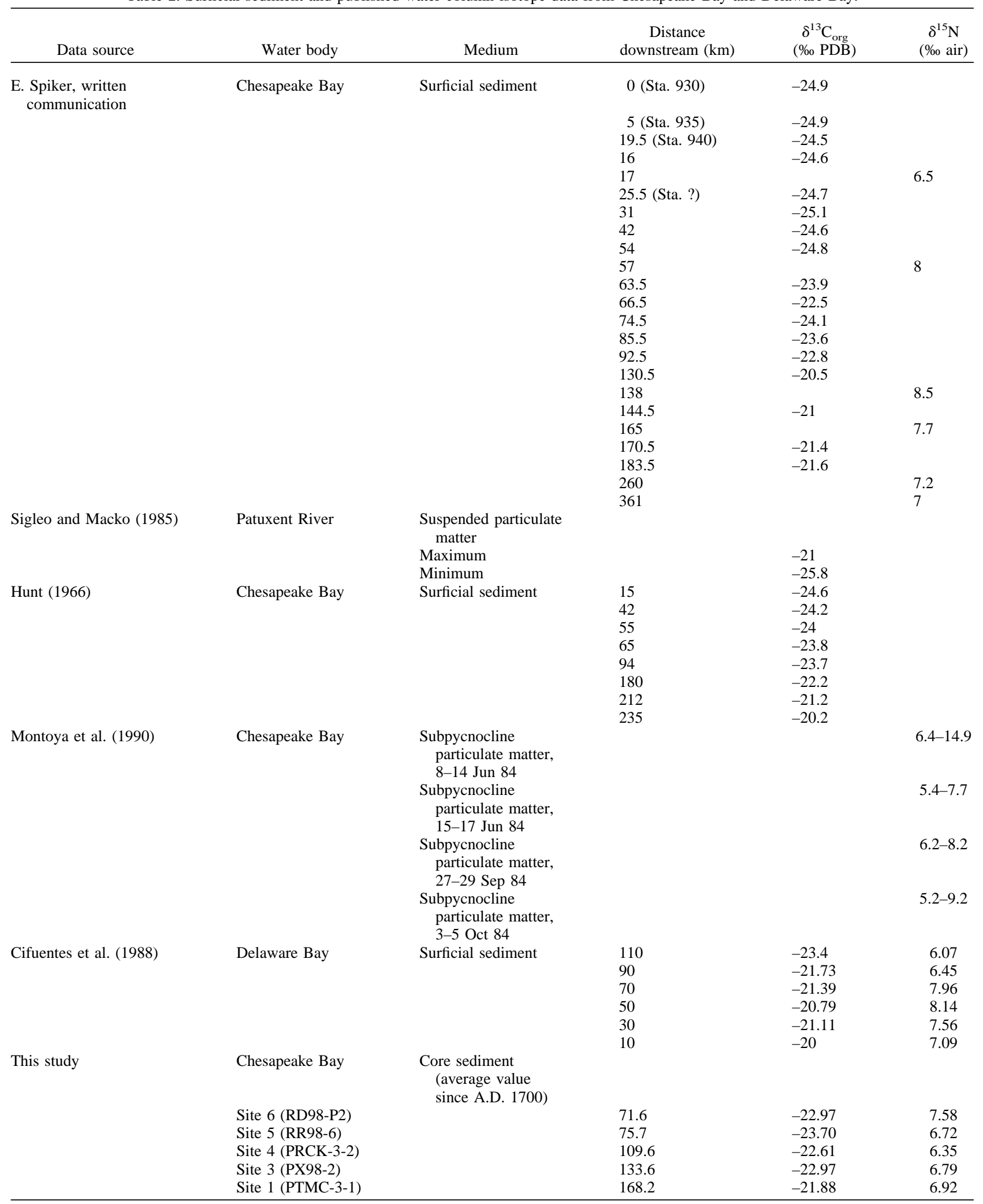

lighter due to incorporation of terrestrial plant material and has a value of $\delta^{13} \mathrm{C}_{\text {org }}<-25 \%$ (see upstream data of Hunt, 1966, shown in Fig. 4A; also Onstad et al., 2000). Sediment sampling across an estuarine or coastal gradient should produce $\delta^{13} \mathrm{C}_{\text {org }}$ measurements that increase in an oceanward direction and span this range (Cifuentes et al., 1988; Lucotte, 1989; Fig. 4A). 
Given the terrestrial and algal sources of organic matter in Chesapeake Bay, the trends in $\mathrm{C} / \mathrm{N}$ of oceanward and basinward (offshore) increases described above are enigmatic. The trends are inconsistent with the expected pattern of decreased contribution of terrestrial organic matter (high $\mathrm{C} / \mathrm{N}$ ) and a larger percentage of algal biomass (low $\mathrm{C} / \mathrm{N}$ ) with increased distance from shore or downstream. This suggests (1) different transport, deposition, and especially diagenetic pathways for the two pools of organic matter, (2) differences between shallow and deep sites, or (3) local influence of detrital matter from tributaries, especially impact of the Potomac River on site 1. The trends in $\delta^{13} \mathrm{C}_{\text {org }}$ data indicate that it may be a more reliable proxy than $\mathrm{C} / \mathrm{N}$ for distinguishing carbon sources in an estuarine setting such as Chesapeake Bay.

Values of $\mathrm{C} / \mathrm{N}$ that deviate by $>+1.5$ from the average ratio described above are the result of unusually high TOC values but $\mathrm{TN}$ values consistent with the rest of the data set. In particular, the site 6 core has anomalously high TOC values between $\sim 1920$ and 1970 that also produce high $\mathrm{C} / \mathrm{N}$ values (up to $15: 1$; Fig. 3 ) and low $\delta^{13} \mathrm{C}_{\text {org }}$ over this interval, indicating unusually high influx of terrestrial organic matter, a decrease in phytoplankton productivity, or more rapid degradation of N-rich compounds (proteins) than C-rich compounds (lipids and carbohydrates) during this time (Lehmann et al., 2002). Since $\delta^{13} \mathrm{C}_{\text {org }}$ data discussed above and productivity data presented by Colman and Bratton (2003) do not indicate major changes in terrestrial influx or decreases in productivity over this time, it is more likely that differential diagenesis of $\mathrm{C}$ and $\mathrm{N}$ produce the $\mathrm{C} / \mathrm{N}$ patterns (Lehmann et al., 2002). The high-C/low-N interval at site 6 (Fig. 3) is probably the result of the advent of three large reservoirs formed by dams constructed on the lower Susquehanna River between 1910 and 1931.

The $\delta^{13} \mathrm{C}_{\text {org }}$ and $\mathrm{C} / \mathrm{N}$ pattern could be explained by the fact that dredging and construction activities during dam building mobilized unusually large quantities of terrestrial OM in disturbed fluvial sediments, which were subsequently transported and deposited at site 6 over the next several decades. Alternatively, trapping of inorganic silt in Susquehanna reservoirs could have caused relative enrichment (less dilution) of TOC in sediments deposited downstream of the dams. Longer residence time of terrestrial organic matter in reservoirs, rather than transport in the undammed river, would produce greater degradation before ultimate deposition in the estuary. This would likely yield $\mathrm{N}$-depleted (high $\mathrm{C} / \mathrm{N}$ ) organic matter (Lehmann et al., 2002) in proximal sediments of northern Chesapeake Bay. The return to more typical $\mathrm{C} / \mathrm{N}$ values at site 6 and lower TOC by $\sim 1970$ is consistent with decreasing sediment trapping efficiency of the dams as their reservoirs filled with sediments (Langland and Hainly, 1997), and generally wetter recent climate conditions (Cronin et al., 2000).

\subsection{Possible Long-Term Freshening Based on $\delta^{13} C_{\text {carbonate }}$}

Limited $\delta^{13} \mathrm{C}_{\text {carbonate }}$ and $\delta^{18} \mathrm{O}$ data were collected by analyzing foraminiferal calcite (Elphidium sp.) from the site 1 and site 4 cores (Fig. 5). Calcareous foraminiferal tests were partially dissolved or completely absent in the majority of core samples. The coarse resolution precludes detailed interpretation of within-core variability, but there is either no overall trend in both cores, or possibly a slight decline toward isotopically lighter $\delta^{13} \mathrm{C}_{\text {carbonate }}$ and $\delta^{18} \mathrm{O}$ values toward the core tops. The average $\delta^{13} \mathrm{C}_{\text {carbonate }}$ gradient is steeper in the site 4 core $\left(\sim 0.5 \% \circ \mathrm{m}^{-1}\right)$ than in the site 1 core $\left(0\right.$ to $\left.0.1 \% \circ \mathrm{m}^{-1}\right)$. Lighter $\delta^{18} \mathrm{O}$ values are consistent with greater input of fresh water or reduced average salinity (Ingram et al., 1996). This $\delta^{18} \mathrm{O}$ trend indicates general freshening of the bay that would be produced by increased runoff and/or gradual infilling of the basin. The differences between the two locations are greater than can be accounted for by differences in sedimentation rates and imply more rapid change overall at the northern core site (4) closer to the Susquehanna River.

The slight trend toward heavier $\delta^{13} \mathrm{C}_{\text {org }}$ in more recent sediments (Fig. 6) contrasts with the $\delta^{13} \mathrm{C}_{\text {carbonate }}$ trend toward lighter values. Freshening of the bay would be expected to result in increased input of isotopically light terrestrial organic matter $\left(\delta^{13} \mathrm{C}_{\text {org }}<-25 \%\right.$ o ) and light dissolved inorganic carbon ( -9 to $-11 \%$; Spiker, 1980; Fogel et al., 1992). It appears, however, that increased input to sediment of algal biomass $\left(\delta^{13} \mathrm{C}_{\text {org }} \approx-20 \%\right.$ o $)$ and $\mathrm{CO}_{2}$ limitation due to eutrophication may be offsetting the expected $\delta^{13} \mathrm{C}_{\text {org }}$ trend in some locations. The $\delta^{13} \mathrm{C}_{\text {carbonate }}$ and $\delta^{18} \mathrm{O}$ patterns may also be the result of diagenetic alteration since, as stated above, calcareous tests of foraminifera from many core intervals were either partially or totally dissolved.

\subsection{Eutrophication and Oxygen Depletion Based on $\delta^{15} \mathrm{~N}$}

In contrast to $\delta^{13} \mathrm{C}_{\text {org }}$ and $\mathrm{C} / \mathrm{N}$ ratios, values for $\delta^{15} \mathrm{~N}$ of sediments are mostly the result of $\mathrm{N}$ cycling within the water column and surficial sediments rather than mixing of terrestrial and marine particulate or dissolved pools. This can be seen in Figure 4B; upstream and downstream values of surficial sediments are both relatively low, $\sim 6$ to $7 \%$, showing no clear difference in isotopic composition of terrestrial vs. marine biomass or dissolved nitrogen sources in this setting. These values are also similar to the background or baseline values shown in Figure 2 for the deeper and older parts of each core. These data indicate that terrestrial organic matter contributed to Chesapeake Bay at present and in the past does not have a distinctive (i.e., heavy) $\delta^{15} \mathrm{~N}$ signature compared with $\delta^{15} \mathrm{~N}$ of marine organic matter. Therefore, enrichment of ${ }^{15} \mathrm{~N}$ in particulate nitrogen in the midbay, and ultimately in sediments, is likely the result of (1) photosynthetic assimilation of heavy residual $\mathrm{NO}_{3}{ }^{-}$or $\mathrm{NH}_{4}{ }^{+}$generated through denitrification and nitrification (Liu and Kaplan, 1989; Horrigan et al., 1990; Montoya, 1994; Brandes and Devol, 1997), and (2) in situ production of residual particulate nitrogen that is isotopically heavy by bacterial breakdown of organic $\mathrm{N}$, and preferential release and removal of isotopically depleted $\mathrm{N}$ species such as $\mathrm{NH}_{4}{ }^{+}$(Wada, 1980).

The expected pattern of diagenesis for $\delta^{15} \mathrm{~N}$ would be similar to the TOC and TN profiles for the cores studied (Fig. 2) but opposite in sign. That is, $\delta^{15} \mathrm{~N}$ of bulk sediment would be expected to get isotopically heavier downcore as ${ }^{14} \mathrm{~N}$ was preferentially removed during decomposition of organic matter (Sachs and Repeta, 1999), but addition of bacterial biomass depleted in ${ }^{15} \mathrm{~N}$ during early diagenesis could counter this effect (Lehmann et al., 2002). While some fractionation of nitrogen isotopes may have taken place during early degrada- 

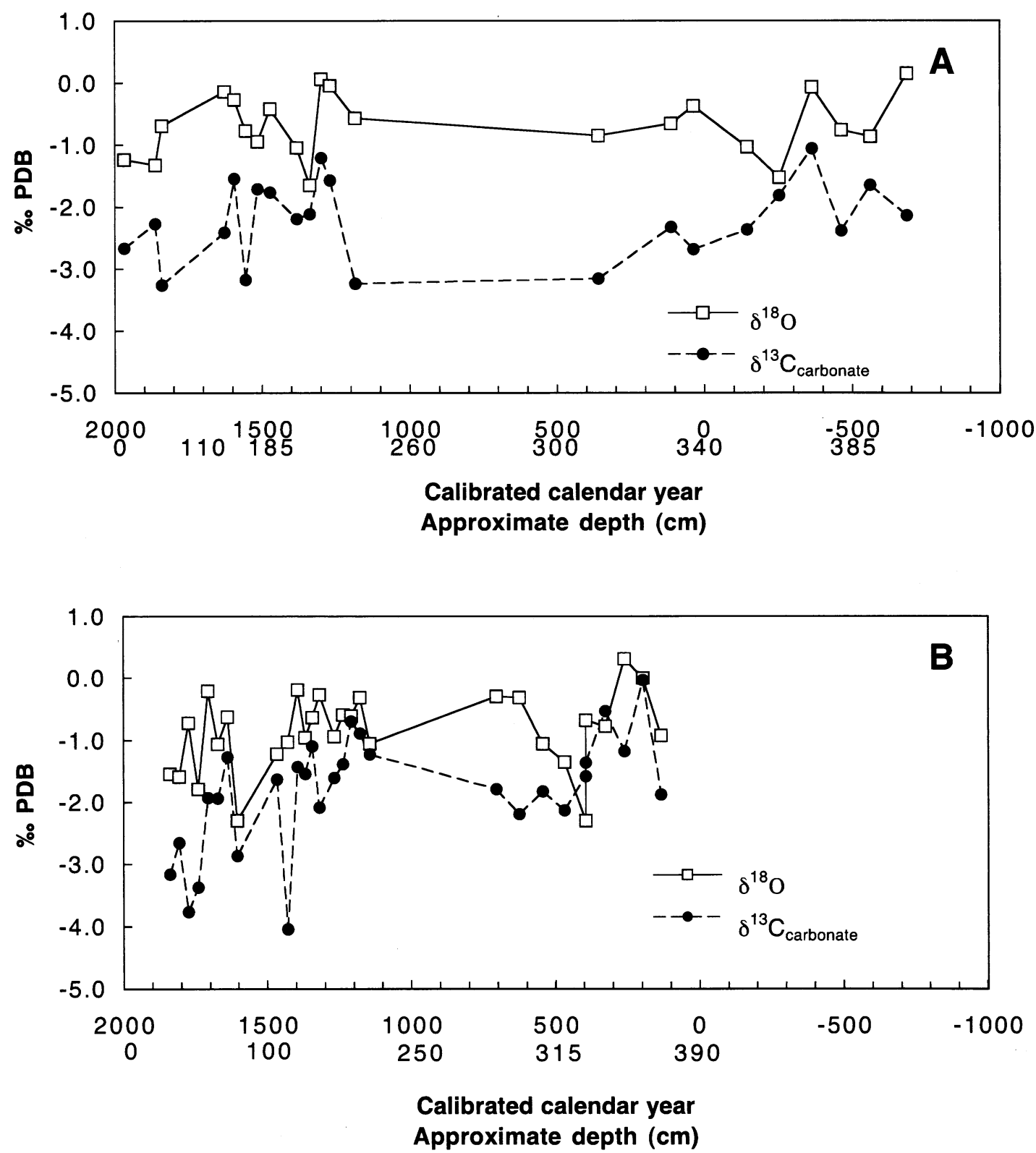

Fig. 5. Results of analyses of $\delta^{13} \mathrm{C}_{\text {carb }}$ and $\delta^{18} \mathrm{O}$ for foraminifera (Elphidium sp.) from cores collected at (A) site 1, and (B) site 4. Irregular sample spacing is due to uneven occurrence or preservation of calcareous tests in the sediment cores.

tion of organic matter at the sediment/water interface, $\delta^{15} \mathrm{~N}$ decreases downcore in all cores. While this could indicate decreased aerobic diagenesis in the past, this interpretation is inconsistent with known oxygen-depleted conditions in deep waters of the modern bay.

Isotopic enrichment of nitrogen can be particularly enhanced by eutrophication and oxygen depletion. These conditions permit significant denitrification to take place not only within suboxic sediments, but within the water column itself where heavy residual nitrogen is closer to the photic zone and more easily recycled than nitrogen derived from sediment processes alone (e.g., Teranes and Bernasconi, 2000). Isotopically depleted $\mathrm{N}_{2}$ and $\mathrm{N}_{2} \mathrm{O}$ are released to the atmosphere. The resulting pattern is a midbay enrichment of $\delta^{15} \mathrm{~N}$ in particulate matter and sediment in the region of maximum productivity, rather than a gradual increasing oceanward trend as seen for $\delta^{13} \mathrm{C}_{\text {org }}$. This is shown in Figure 4B and Table 2.

While ${ }^{15} \mathrm{~N}$ enrichment of particulate matter can take place due to enhanced aerobic remineralization (decomposition) and nitrification alone without significant denitrification and oxygen depletion, denitrification produces the greatest positive fractionation (up to $+40 \%$ o) of any of the biologic processes that affect the isotopic composition of nitrogen (Montoya, 1994). Therefore, the isotopic impact of even a small amount of denitrification on the nitrogen pool can be greater than that produced by a much larger amount of nitrification or remineralization.

Reconstruction of original $\delta^{15} \mathrm{~N}$ of deposited particulates is 


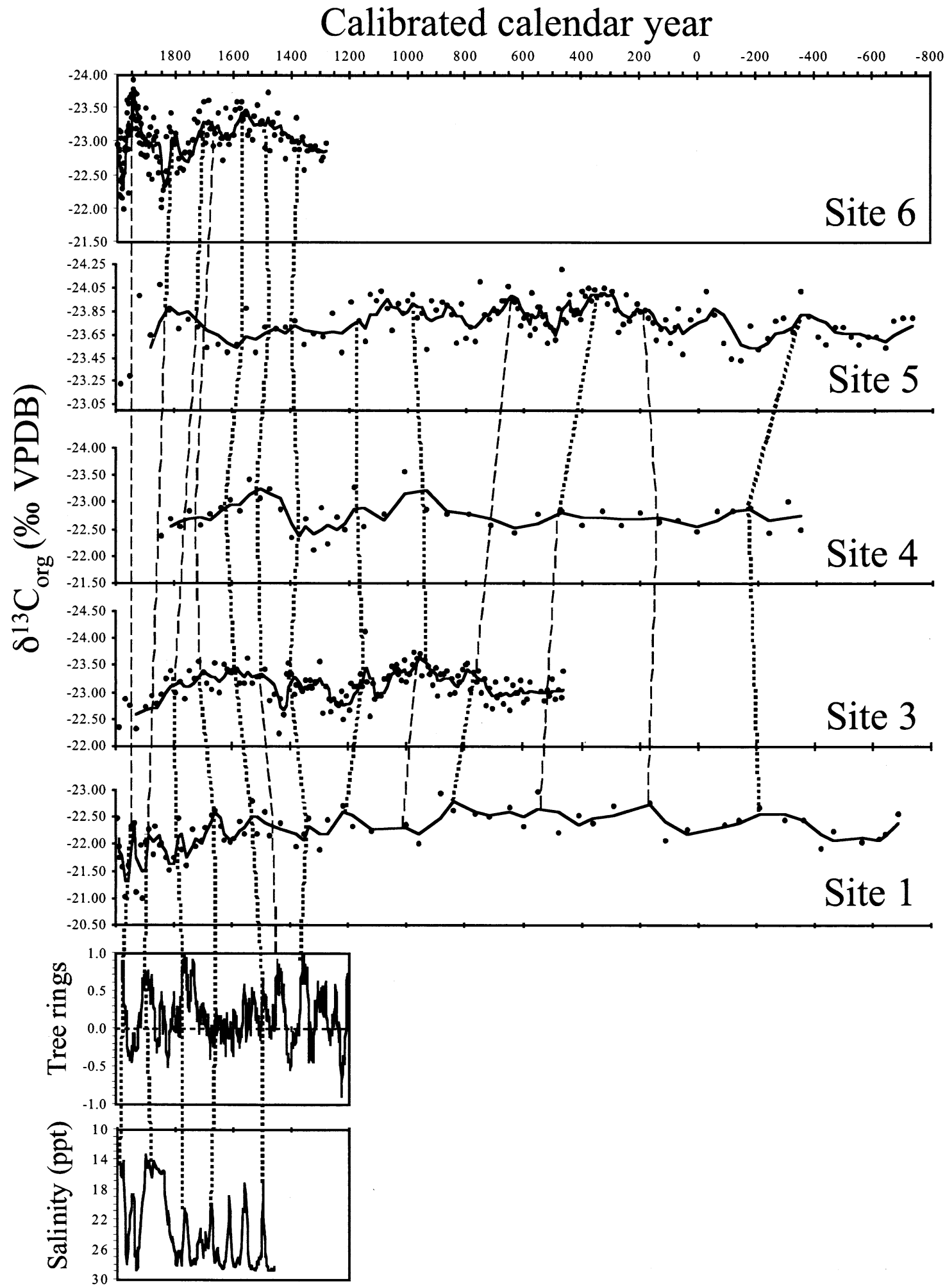

Fig. 6. Values of $\delta^{13} \mathrm{C}_{\text {org }}$ for all cores plotted against calendar year (negative values = B.C.) based on age models from Colman et al. (2002). Solid lines are moving averages adjusted to match differences in resolution among cores (sites 1, 3, 4, 5, and 6; 2-point, 4-point, 2-point, 4-point, and 6-point moving averages, respectively). Dotted lines connect peaks in at least two cores corresponding to periods of lighter or more terrestrial isotope values (note reversed axes), consistent with increased precipitation and decreased salinity. Correlation lines are dashed where matching peaks are absent or only weakly resolved in data sets. Tree ring data reported as Palmer Hydrologic Drought Index (PHDI) (Stahle et al., 1998) and paleosalinity based on foraminifera (Cronin et al., 2000) are also shown in the bottom two panels for comparison. 
easiest for anoxic sediments. This is because aerobic diagenesis can both significantly enrich and slightly deplete $\delta^{15} \mathrm{~N}$ of residual organic matter, while anoxic diagenesis consistently depletes $\delta^{15} \mathrm{~N}$ by $<-3 \%$ (Sachs and Repeta, 1999; Lehmann et al., 2002). Increasing severity in terms of time, space, and concentration of oxygen depletion in subpycnocline waters and sediments of Chesapeake Bay since at least 1950 (Officer et al., 1984) would promote less aerobic decomposition over this time period rather than more. Therefore, the observed trend of heavier $\delta^{15} \mathrm{~N}$ since 1950 (and, by extrapolation, before) must have been produced by a mechanism other than enhanced aerobic decomposition (or sediment nitrification), at least within the deep parts of the bay. Trends such as increasing ventilation and bioturbation, and decreasing sedimentation rates that would enhance decomposition and nitrification in the water column, or denitrification within sediments, have not been observed in Chesapeake Bay. On the contrary, benthic foraminifera tolerant of low-oxygen conditions in bottom water appeared in Chesapeake Bay in the late 1600s, and have generally increased in abundance since then (Karlsen et al., 2000). This indicates that changes in water column processes probably played a major role in producing the observed $\delta^{15} \mathrm{~N}$ change, rather than changes in sediment processes alone.

North-south transects (Fig. 4B) of surface sediments in Delaware Bay (Cifuentes et al., 1988) and suspended particulates in Chesapeake Bay (Montoya et al., 1990, 1991) showed midbay peaks in $\delta^{15} \mathrm{~N}$ of up to $8.14 \%$ o 60 to $80 \mathrm{~km}$ south of the Delaware River, and $15.0 \% \circ 110 \mathrm{~km}$ south of the Susquehanna River, respectively. Data from Chesapeake Bay surface sediments (E. Spiker, written communication) show a peak of $8.5 \%$ $140 \mathrm{~km}$ south of the Susquehanna River (near site 4) in the same region as the water column peak in POC (Montoya et al., $1990,1991)$. Sediment values are 1 to $2 \%$ lower to the north and south in both bays.

It is likely that eutrophication of the bay is the result of input of excess nitrogen from human sources (e.g., eroded soil, fertilizer, wastewater, and atmospheric deposition), including several with heavy $\delta^{15} \mathrm{~N}$ (Teranes and Bernasconi, 2000). The proximal input of isotopically heavy dissolved nitrogen from wastewater treatment plants in Baltimore and Washington, D.C. in particular would be expected to affect the $\delta^{15} \mathrm{~N}$ of organic matter in the northern bay, especially at sites 1 and 6 . However, the spatial pattern (midbay maximum [near site 4] vs. upstream or tributary mouth maximum) and the magnitude of the $\delta^{15} \mathrm{~N}$ enrichment observed in suspended particulates and sediments indicates that the enrichment was probably produced in situ, rather than resulting from input of allochthonous $\delta^{15} \mathrm{~N}$ enriched nitrate, ammonium, or particulates (Montoya et al., 1990, 1991; Montoya, 1994; Zimmerman and Canuel, 2002). Boynton et al. (1995) estimated that denitrification removes $26 \%$ of the annual input of nitrogen to Chesapeake Bay from all sources, so it is not unreasonable to expect this mechanism to impart an enriched isotopic signature to sedimentary TN. Further sampling of tributary sediments for $\delta^{15} \mathrm{~N}$ analysis, however, especially those tributaries that receive significant municipal and industrial wastewater effluent (e.g., the Potomac), would be necessary to completely rule out contribution of allochthonous $\delta^{15} \mathrm{~N}$-enriched sources to the midbay enrichment.

Furthermore, the $\delta^{15} \mathrm{~N}$ enrichment probably was not pro- duced from variable nitrate utilization, as is observed in the open ocean (e.g., Altabet and François, 1994), since the estuary is always nitrate limited. The situation in Chesapeake Bay is more analogous to settings where the oxygen minimum zone impinges on the seafloor, such as the eastern tropical north Pacific (Ganeshram et al., 2000) or the Arabian Sea (Altabet et al., 1999), and significant denitrification in the suboxic water column takes place.

\subsection{Correlation of $\delta^{13} C_{o r g}$ and $\delta^{15} N$ Patterns Among Cores}

Figure 6 shows $\delta^{13} \mathrm{C}_{\text {org }}$ profiles for the five cores plotted against calendar year (age models from Colman et al., 2002) spanning the last $2700 \mathrm{yr}$. The age of the base of the core from site 6 is only $\sim 750 \mathrm{yr}$; this is significantly younger than other cores due to the high sedimentation rate at this location. Small offsets and mismatches in curves are due to uncertainties in the age models, uneven recovery of shallowest sediments in different cores, irregular sedimentation rates, and lower resolution in cores from sites 1,4 and 5. If it is assumed that lighter $\delta^{13} \mathrm{C}_{\text {org }}$ indicates primarily greater input of terrestrial organic matter due to wetter climate conditions and more river discharge, the profiles show $\sim 5$ to 13 wet periods (wet peaks connected by dashed lines in Fig. 6) over the last $2700 \mathrm{yr}$. Cycles are not numbered to avoid confusion with the highresolution scheme of Cronin et al. (2000), which covered about one fifth of the time scale examined here (550 vs. $2700 \mathrm{yr}$ ).

Significant wet periods (longer or more intense) distinguished by lower $\delta^{13} \mathrm{C}_{\text {org }}$ (peaks on Fig. 6 due to reversed axes) are centered on the following years: A.D. 1935, 1800, 1560, and 970; and 300 B.C. Similarly noteworthy dry periods are centered on A.D. 1960, 1820, 1610, 1250, 1080, 300, 50; and 600 B.C. The dry period at $\sim 1600$ may correlate with the Jamestown and Roanoke Island droughts of 1587 to 1589 and 1606 to 1612 , respectively, as discussed by Stahle et al. (1998) and Cronin et al. (2000). The droughts of the 1950s and 1960s were followed by three decades of generally higher river discharge to the bay. This transition period from dry to wet corresponded with a period of heightened public awareness of degraded conditions in the bay and reports of increasing summer oxygen depletion (Officer et al., 1984). As discussed above, a slight trend toward heavier $\delta^{13} \mathrm{C}_{\text {org }}$ in some cores in sediments deposited since around A.D. 1750 to 1800 may be the result of eutrophication, which would increase both algal input to sediment and $\mathrm{CO}_{2}$ limitation.

All five cores show that a strong rising trend in $\delta^{15} \mathrm{~N}$ of POC began in the bay around A.D. 1750 to 1800 (Figs. 7 and 8), coincident with significant land clearing for agriculture by colonists. This transition is supported by historical records and the appearance of abundant Ambrosia (ragweed) pollen in cores (Cooper, 1995). Typically, the values increase by 2 to $4 \%$, possibly in two pulses (see sites 1 and 6 especially, since the upper part of the site 4 record is missing). This increase is greater than the total variability of modern bay sediments (Fig. 4B; see also Cifuentes et al., 1988; Montoya et al., 1990). Similar $\delta^{15} \mathrm{~N}$ data have been reported for the Schelde estuary (Middelburg and Nieuwenhuize, 1998) and from Mississippi River plume sediments (Eadie et al., 1994) and have been linked to nutrient enhancement of productivity and denitrifica- 


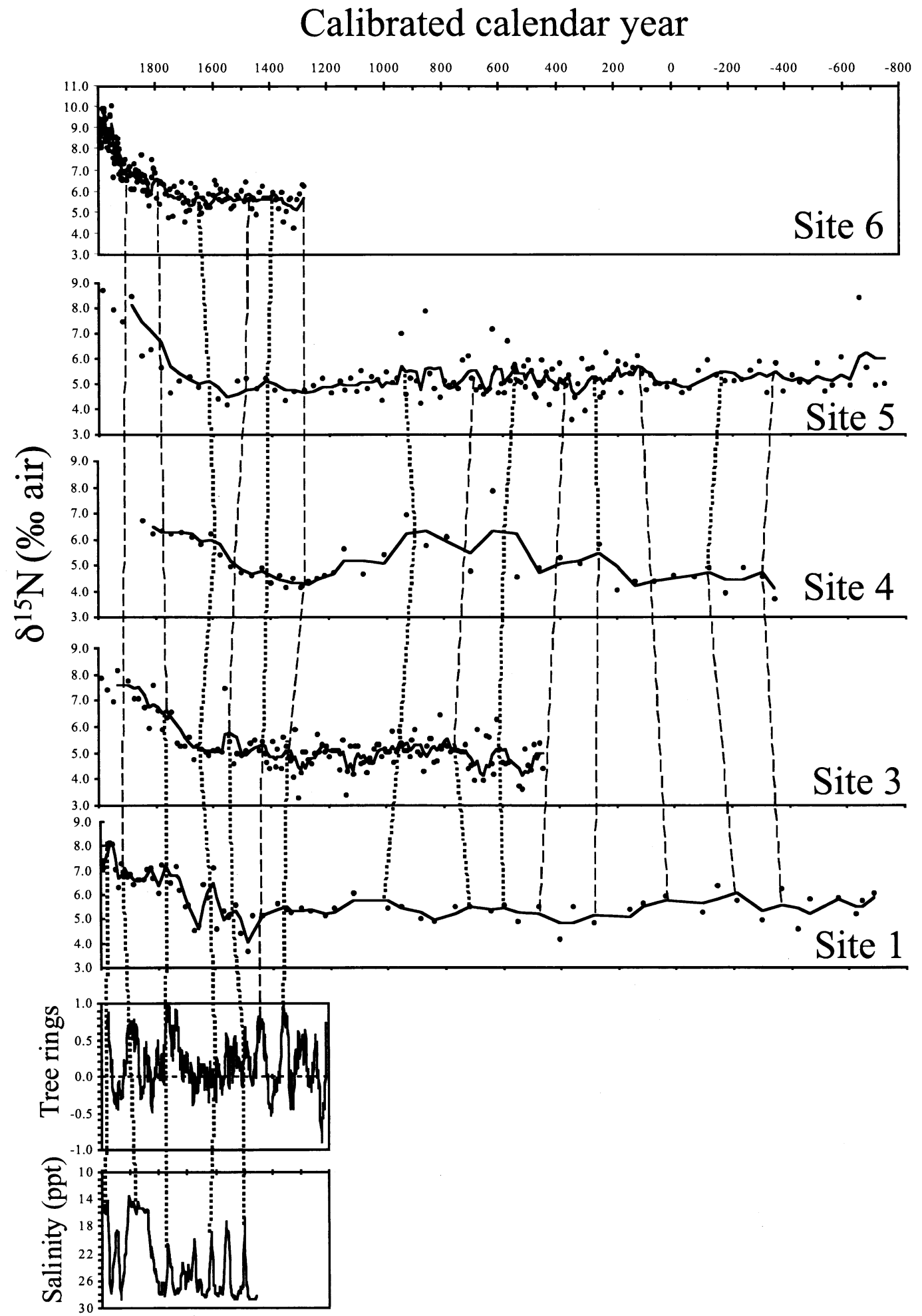

Fig. 7. Values of $\delta^{15} \mathrm{~N}$ for all cores plotted against calendar year (negative values = B.C.) based on age models from Colman et al. (2002). Solid lines are moving averages adjusted to match differences in resolution among cores (sites 1, 3 , 4, 5, and 6; 2-point, 4-point, 2-point, 4-point, and 6-point moving averages, respectively). Dotted lines connect peaks in at least two cores corresponding to periods of heavier isotope values produced by increased denitrification and decomposition of organic nitrogen consistent with increased spring runoff, higher nutrient loading, increased productivity, and greater oxygen depletion. Correlation lines are dashed where expected peaks are absent or only weakly resolved in data sets. Tree ring data reported as PHDI (Stahle et al., 1998), and paleosalinity based on foraminifera (Cronin et al., 2000) are also shown in the bottom two panels for comparison. 


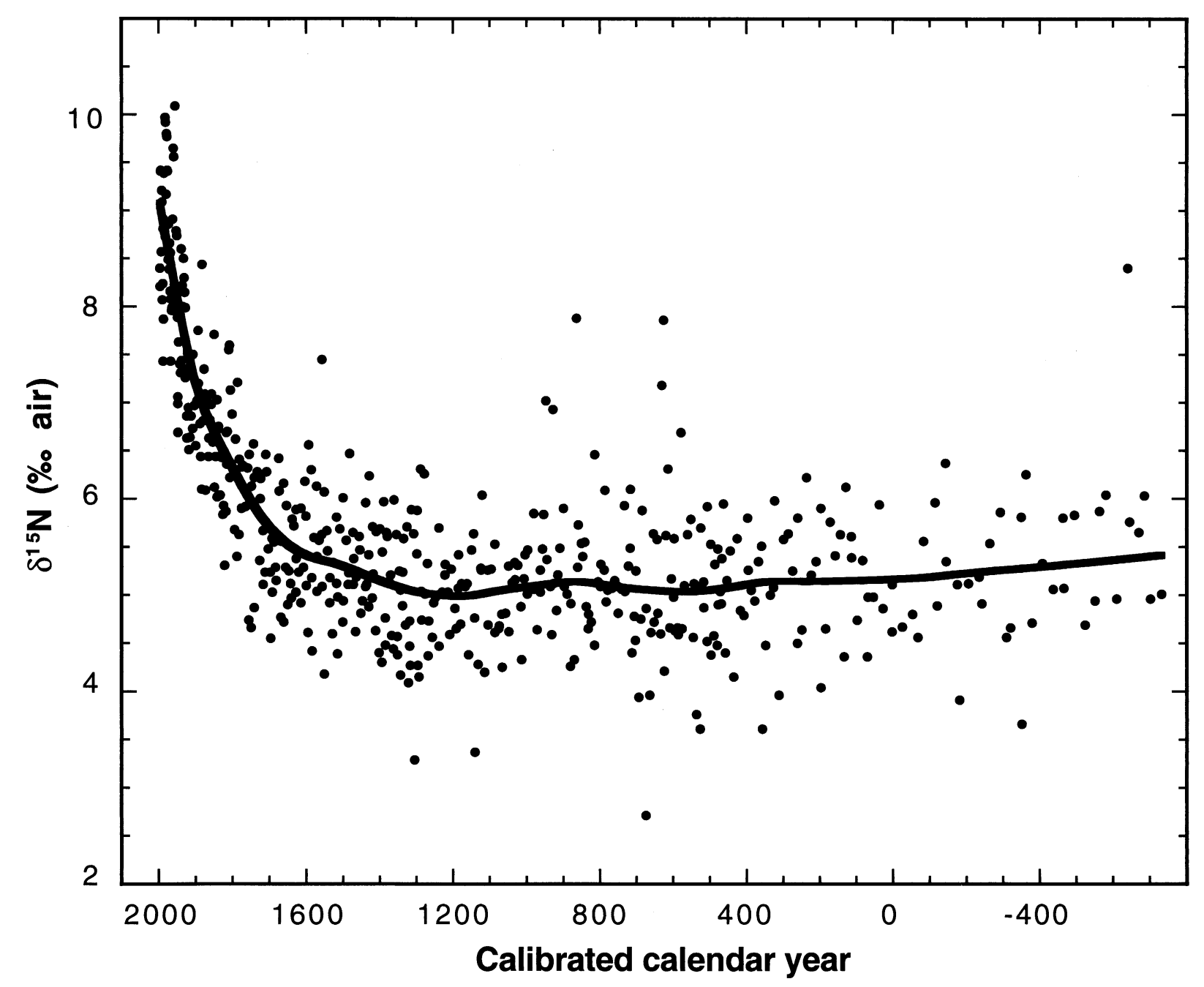

Fig. 8. Composite plot of all $\delta^{15} \mathrm{~N}$ data from all cores $(\mathrm{n}=549)$ showing the transition from $\sim 2500 \mathrm{yr}$ of nearly constant or slightly decreasing average values to ${ }^{15} \mathrm{~N}$-enriched values after about A.D. 1750 to 1800 This pattern is consistent with anthropogenic eutrophication, increased denitrification, and increased oxygen depletion. Negative calendar years are B.C. The curve shown is a locally weighted least squared error fit to the data.

tion, rather than heavy $\delta^{15} \mathrm{~N}$ signatures associated with changing nitrogen sources.

The Chesapeake increase suggests that the magnitude of the change in nitrogen fractionation in the mesohaline bay between 1750 to 1800 and the present (Fig. 8) was greater than the magnitude of the modern difference between the $\delta^{15} \mathrm{~N}$ maximum area, characterized by large algal blooms, and zones well outside of the bloom region (Fig. 4B). This indicates that at least the entire northern bay (Maryland portion) has experienced significant eutrophication and increases in both intensity and extent of algal blooms relative to background conditions before 1750 . The pattern is consistent from core to core despite sedimentation rates that vary by $>1$ order of magnitude indicating that the trend cannot be diagenetic. The observed $\delta^{15} \mathrm{~N}$ increase indicates an increase in denitrification, following the reasoning above. Such an increase would have initially taken place within sediments under an oxygenated water column, but the marked, sustained, and increasing enrichment is best explained by the development of oxygen depletion within the water column.

Water-column anoxia may be necessary to allow nitrogen from spring blooms to fuel productivity throughout the summer, as has been demonstrated for Chesapeake Bay (Baird et al., 1995). This guarantees that isotopically heavy nitrogen produced by denitrification and other mechanisms can be incorporated into biomass and deposited in sediment in particulate form. Therefore, the conclusion most consistent with the $\delta^{15} \mathrm{~N}$ data (Fig. 8) is that significant and consistent depletion of oxygen during the summer in Chesapeake Bay waters began at the same time as, and was likely caused by, agricultural development of the watershed. The signal is unprecedented in the 2700 -yr data set; there is also no obvious break in the enrichment trend between the modern conditions (summer anoxia) and the beginning of the trend $250 \mathrm{yr}$ ago that would indicate a change in mechanism for the $\delta^{15} \mathrm{~N}$ enrichment. Significant nutrient inputs from wastewater discharge and application of 


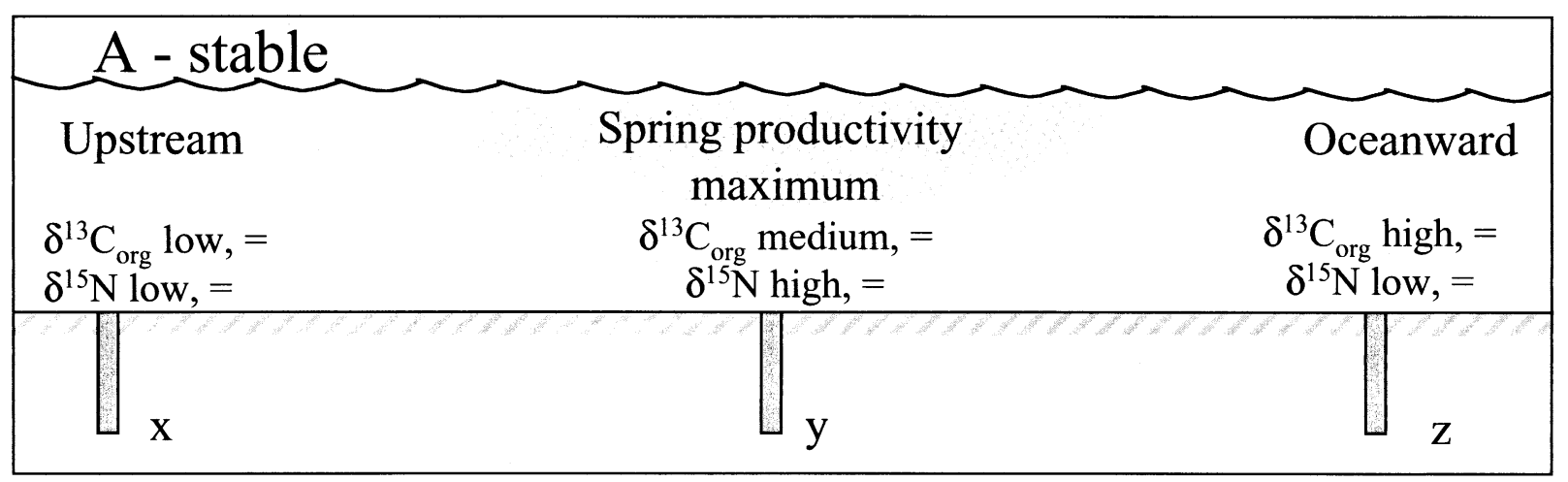

\begin{tabular}{|c|c|c|}
\hline \multicolumn{3}{|c|}{ B - shifting upstream } \\
\hline $\begin{array}{l}\text { Upstream } \\
\delta^{13} \mathrm{C}_{\text {org }} \text { low, } \uparrow \\
\delta^{15} \mathrm{~N} \text { low, } \uparrow\end{array}$ & $\begin{array}{c}\text { Spring productivity } \\
\text { maximum } \\
\delta^{13} \mathrm{C}_{\text {org }} \text { medium, } \uparrow \\
\delta^{15} \mathrm{~N} \text { high, } \downarrow\end{array}$ & $\begin{array}{c}\text { Oceanward } \\
\delta^{13} \mathrm{C}_{\text {org }} \text { high, } \uparrow \\
\delta^{15} \mathrm{~N} \text { low, }=\end{array}$ \\
\hline$U_{x}$ & $U_{y}$ & $\mathrm{Z}$ \\
\hline
\end{tabular}

\begin{tabular}{|c|c|c|}
\hline \multicolumn{3}{|c|}{$\mathrm{C}$ - shifting oceanward } \\
\hline $\begin{array}{l}\text { Upstream } \\
\delta^{13} \mathrm{C}_{\text {org }} \text { low, } \downarrow \\
\delta^{15} \mathrm{~N} \text { low, }=\end{array}$ & $\begin{array}{c}\text { Spring productivity } \\
\text { maximum } \\
\delta^{13} \mathrm{C}_{\text {org }} \text { medium, } \\
\delta^{15} \mathrm{~N} \text { high, } \downarrow\end{array}$ & $\begin{array}{l}\text { Oceanward } \\
\delta^{13} \mathrm{C}_{\text {org }} \text { high, } \downarrow \\
\delta^{15} \mathrm{~N} \text { low, } \uparrow\end{array}$ \\
\hline$U_{x}$ & $U_{y}$ & $\mathrm{Z}$ \\
\hline
\end{tabular}

Fig. 9. Schematic diagrams of models for interpretation of $\delta^{13} \mathrm{C}_{\text {org }}$ and $\delta^{15} \mathrm{~N}$ patterns in cores based on positions of coring locations relative to the spring productivity maximum.

inorganic fertilizer in the last century (Zimmerman and Canuel, 2000) are likely to have exacerbated, rather than initiated, the problem.

Superimposed on the $\delta^{15} \mathrm{~N}$ trends are shorter fluctuations similar to those seen in $\delta^{13} \mathrm{C}_{\text {org }}$ profiles but not as clearly developed (Figs. 6 and 7, especially high-resolution cores from sites 3 and 6). Decadal to centennial wet-dry cycles should affect $\delta^{15} \mathrm{~N}$ as well as $\delta^{13} \mathrm{C}_{\text {org }}$ because delivery of more nutrients to the estuary during wetter intervals would be expected to produce heavier $\delta^{15} \mathrm{~N}$ values in areas impacted by more intense and widespread algal blooms and denitrification. Dry periods should produce the opposite effects. Except for a few $\delta^{15} \mathrm{~N}$ data points $>6 \%$ o between A.D. 500 and 1000 in cores from sites 3, 4, and 5 (Figs. 7 and 8), there is no evidence of significant denitrification and associated oxygen depletion in any core before $\sim 1750$. These few anomalous points may represent brief periods of natural precolonial oxygen depletion in the bay due to unusually wet spring conditions. Alternatively, they could be products of diagenesis or analytical artifacts.

Based on the interpretation of carbon isotopes described above, $\delta^{15} \mathrm{~N}$ and $\delta^{13} \mathrm{C}_{\text {org }}$ should generally be inversely correlated (i.e., more positive $\delta^{15} \mathrm{~N}$ values during wet intervals should correspond to more negative $\delta^{13} \mathrm{C}_{\text {org }}$ values derived from more terrestrial carbon input). This relationship is complicated by the location of the core sites relative to the areas of large algal blooms. For example, a location on the northern (upstream) side of the typical bloom maximum shows a decrease in both $\delta^{15} \mathrm{~N}$ and $\delta^{13} \mathrm{C}_{\text {org }}$ during a wet period. Such a scenario develops because increased runoff pushes the bloom maximum further south (Fig. 9, scenario C) resulting in less denitrification at the site and deposition of organic matter with a more terrestrial carbon signature. On longer timescales the 


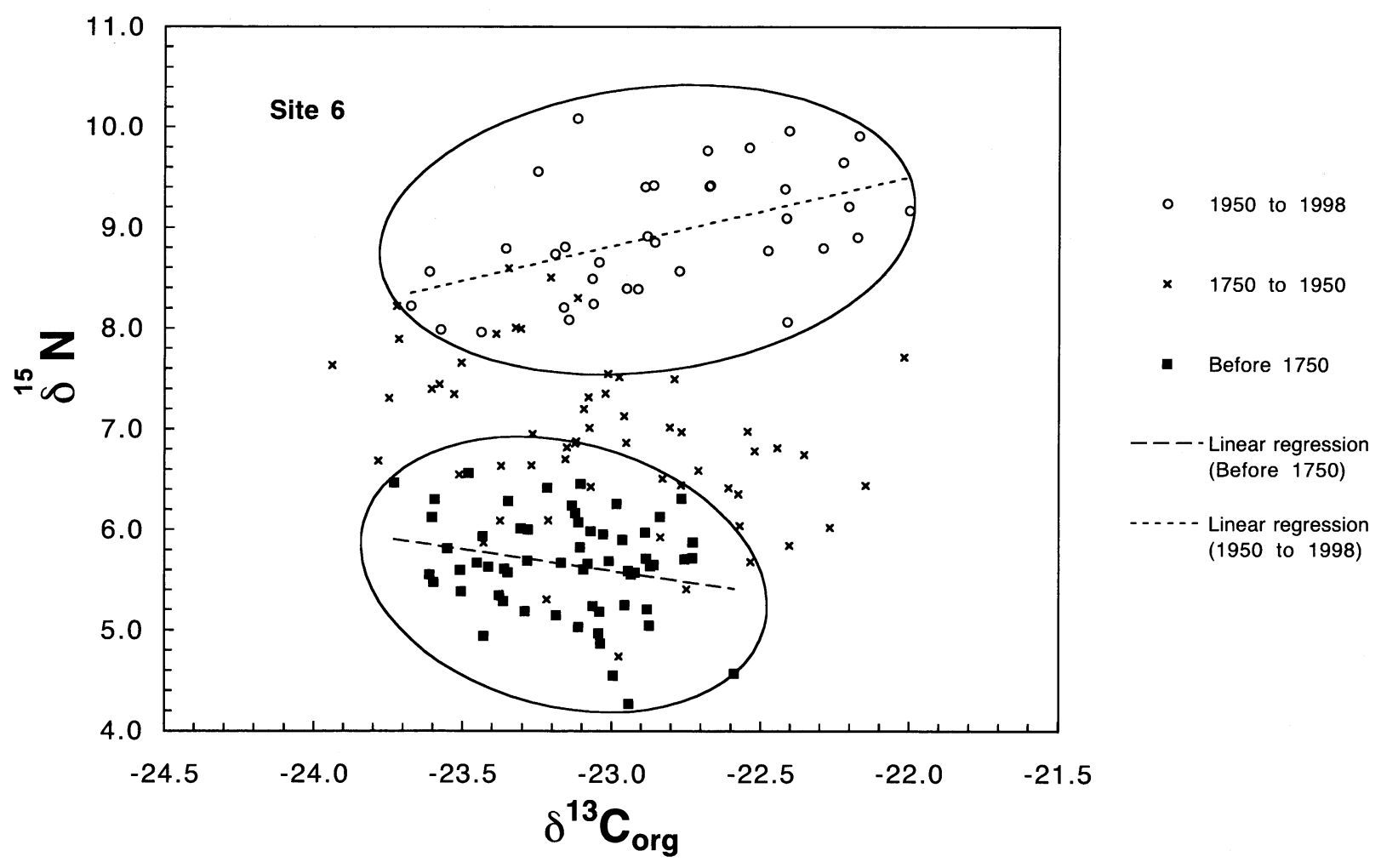

Fig. 10. Crossplot of $\delta^{13} \mathrm{C}_{\text {org }}$ and $\delta^{15} \mathrm{~N}$ data for core site 6 showing the transition from negative correlation before 1750 to positive correlation after 1950 .

same pattern could be produced by infilling of the basin, basin uplift, reforestation, or falling sea level. The opposite situation is produced by a dry period (Fig. 9, scenario B) resulting in migration of the bloom maximum upstream and decreased size of the bloom due to lower nutrient flux to the bay. The steady state situation corresponds to scenario A in Figure 9.

Given these constraints, the modern situation at the five core sites studied can be generally classified as having $\mathrm{C}$ and $\mathrm{N}$ isotopes positively correlated (Scenario A, position " $\mathrm{x}$ " to " $\mathrm{y}$," on Fig. 9) for the most recent wet-dry cycles. This characterization derives from the modern location of the maximum of the spring diatom bloom in the midbay between the Patuxent River and the Rappahannock River ( $~ 38.7$ to $37.5^{\circ} \mathrm{N}$ latitude), based on plankton tows, chlorophyll measurements, and remote sensing of chlorophyll concentrations from aircraft (Harding and Perry, 1997). The classifications change for some locations going further back in time. For example, the site 6 core shows a weak positive correlation between $\delta^{15} \mathrm{~N}$ and $\delta^{13} \mathrm{C}_{\text {org }}$ since 1950 (positive slope), no correlation between 1750 and 1950, and a weak inverse correlation (negative slope) before 1750 (Fig. 10). This is consistent with a southward migration of the spring productivity maximum over this time period (about the last $750 \mathrm{yr}$ ) from an area upstream of core site 6 in the past, to a zone oceanward of the site at present. Such a pattern would result from progressive progradation of the Susquehanna "delta" in the northern bay and infilling of the axial basin, or increasingly wet climate conditions. The influence of dam construction, as discussed above, is probably important here too.

\subsection{Paleoclimatic Context}

If the precolonial variations in carbon and nitrogen isotopes in Chesapeake Bay sediments largely reflect variations in runoff to the bay, then comparison with paleoclimate records is warranted. Like faunal-based indicators of salinity in the bay (Cronin et al., 2000), the isotopic records show decadal-scale variation. These decadal-scale wet-dry cycles may be related to drought cycles in the southeastern U.S. (Stahle et al., 1998; Cronin et al., 2000), and may also be related to climate-system oscillations such as the North Atlantic Oscillation (Cronin et al., 2000).

Multi-century scale climate variations, however, such as those referred to as the Medieval Warm period (MWP) (about A.D. 1000-1300) and the Little Ice Age (LIA) (about A.D. 1450-1850) are not readily apparent in our data or in the faunal-based salinity estimates. Climate fluctuations, especially MWP warming and LIA cooling, are observed in many parts of the world (most recent discussions in Crowley, 2000, and Mann, 2000), although the global significance and scale of these events have been questioned (Hughes and Diaz, 1994). The best records are commonly those for temperature, many of which show an amelioration during the LIA centered on about A.D. 1700; but even then, timing may vary regionally (Mann, 2000). Significant variations in sea-surface temperature have been documented offshore of Chesapeake Bay on the Bermuda Rise during the MWP and LIA (Keigwin, 1996). Records of precipitation and runoff related to these events appear to be less consistent and more regionally variable than those for temper- 
ature (Crowley and North, 1991). It may be that century-scale variations in moisture conditions in the Chesapeake Bay watershed were minor, such that the most apparent system response was to decadal scale drought patterns. Since about A.D. 1750 to 1800 , any climatic signals that are present have been heavily overprinted by anthropogenic effects, decreasing the likelihood of detecting any subtle signals. That said, attribution of significant forcing of postcolonial changes in Chesapeake Bay conditions to amelioration of LIA climate is unwarranted, since the magnitude of recent changes is unprecedented over the $2500 \mathrm{yr}$ of the core record where climate alone drove the system.

\subsection{Application to Other Estuaries}

These data provide time-averaged baseline information that can be integrated with modern monitoring programs to detect expected recovery of the system as nutrient loading is reduced. For example, reversal of eutrophication should result in shrinkage of the area of surficial sediments with elevated $\delta^{15} \mathrm{~N}$, and decreasing $\delta^{15} \mathrm{~N}$ values in the center of the region of maximum productivity. Values of $\delta^{13} \mathrm{C}$ should also decrease as autochthonous organic matter input decreases.

The length and resolution of the water quality data set that exists for Chesapeake Bay is among the best available for any estuary in the world, but the data presented here put it into a much larger time and space context. This approach could be productively applied to assess the health of other developed estuaries relative to their pristine conditions and relative to different climatic regimes, especially where historical water quality data are limited or absent. This should lead to better understanding of general biogeochemical evolution of estuaries and their role in global $\mathrm{C}$ and $\mathrm{N}$ cycling, as well as improved ability to design effective management and remediation strategies for degraded estuarine ecosystems and resources.

Acknowledgments - We thank Thomas Cronin for supplying samples and paleosalinity data, and David Stahle for use of tree ring data. We appreciate the analytical contributions of Pattie Baucom, Gregory Wandless, Adam Johnson, Dorinda Ostermann, William Curry, Jason Yonehiro, and Theresa Barber. We also thank Richard Younger, captain of $R / V$ Discovery (now $R / V$ Kerhin); Jeffrey Halka; Ellen Mecray; Andrew Zimmerman; and Alex Karlsen for valuable contributions during coring and sampling operations. Daniel McCorkle, Steven Petsch, Peter Swarzenski, Simon Sheppard, and four anonymous reviewers provided helpful comments on drafts of this manuscript. Any use of trade, product, or firm names is for descriptive purposes only and does not imply endorsement by the U.S. government.

Associate editor: S. M. F. Sheppard

\section{REFERENCES}

Adelson J. M., Helz G. R., and Miller C. V. (2001) Reconstructing the rise of recent coastal anoxia; molybdenum in Chesapeake Bay sediments. Geochim. Cosmochim. Acta 65, 237-252.

Altabet M. A. and François R. (1994) Sedimentary nitrogen isotopic ratio records surface ocean nitrate utilization. Glob. Biogeochem. Cycles 8, 103-116.

Altabet M. A., Murray D. W., and Prell W. L. (1999) Climatically linked oscillations in Arabian Sea denitrification over the past $1 \mathrm{~m}$. y.; implications for the marine $\mathrm{N}$ cycle. Paleoceanography 14, 732-743.
Baird D., Ulanowicz R. E., and Boynton W. R. (1995) Seasonal nitrogen dynamics in Chesapeake Bay: A network approach. Estuar. Coast. Shelf Sci. 41, 137-162.

Baucom P. C., Bratton J. F., Colman S. M., Moore J. M., King J., Heil C., and Seal R. (2001) Selected Data for Sediment Cores Collected in Chesapeake Bay in 1996 and 1998. USGS Open-File Report 01-194.

Boehme S. E., Blair N. E., Chanton J. P., and Martens C. S. (1996) A mass balance of ${ }^{13} \mathrm{C}$ and ${ }^{12} \mathrm{C}$ in an organic-rich methane-producing marine sediment. Geochim. Cosmochim. Acta 60, 3835-3848.

Boynton W. R., Kemp W. M., Barnes J. M., Matteson L. L., Rohland F. M., Jasinski D. A., and Kimble H. L. (1993) Chesapeake Bay Water Quality Monitoring Program, Level One Data Report \#10, Part 1: Interpretive Report.

Boynton W. R., Garber J. H., Summers R., and Kemp W. M. (1995) Input, transformations, and transport of nitrogen and phosphorus in Chesapeake Bay and selected tributaries. Estuaries 18, 285-314.

Brandes J. A. and Devol A. H. (1997) Isotopic fractionation of oxygen and nitrogen in coastal marine sediments. Geochim. Cosmochim. Acta 61, 1793-1801.

Brush G. S. (1984) Stratigraphic evidence of eutrophication in an estuary. Wat. Res. Res. 20, 531-541.

Cifuentes L. A., Sharp J. H., and Fogel M. L. (1988) Stable carbon and nitrogen isotope biogeochemistry in the Delaware estuary. Limnol. Oceanogr. 33, 1102-1115.

Colman S. M. and Bratton J. F. (2003) Anthropogenically induced changes in sediment and biogenic silica fluxes in Chesapeake Bay. Geology 31, 71-74.

Colman S. M., Baucom P. C., Bratton J. F., Cronin T. M., McGeehin J. P., Willard D., Zimmerman A. R., and Vogt P. R. (2002) Radiocarbon dating, chronologic framework, and changes in accumulation rates of Holocene estuarine sediments from Chesapeake Bay. Quat. Res. 57, 58-70.

Cooper S. R. (1995) Chesapeake Bay watershed historical land use: Impact on water quality and diatom communities. Ecol. Appl. 5, 703-723.

Cooper S. R. and Brush G. S. (1991) Long-term history of Chesapeake Bay anoxia. Science 254, 992-996.

Cooper S. R. and Brush G. S. (1993) A 2,500-year history of anoxia and eutrophication in Chesapeake Bay. Estuaries 16, 617-626.

Cornwell J. C., Conley D. J., Owens M., and Stevenson J. C. (1996) A sediment chronology of the eutrophication of Chesapeake Bay. Estuaries 19, 488-499.

Cowan J. L. W. and Boynton W. R. (1996) Sediment-water oxygen and nutrient exchanges along the longitudinal axis of Chesapeake Bay: Seasonal patterns, controlling factors and ecological significance. Estuaries 19, 562-580.

Cronin T., Willard D., Karlsen A., Ishman S., Verardo S., McGeehin J., Kerhin R., Holmes C., Colman S., and Zimmerman A. (2000) Climatic variability in the eastern United States over the past millennium from Chesapeake Bay sediments. Geology 28, 3-6.

Crowley T. J. (2000) Causes of climate change over the past 1000 years. Science 289, 270-277.

Crowley T. J. and North G. R. (1991) Paleoclimatology. Oxford University Press, New York.

Eadie B. J., McKee B. A., Lansing M. B., Robbins J. A., Metz S., and Trefry J. H. (1994) Records of nutrient-enhanced coastal ocean productivity in sediments from the Louisiana Continental Shelf. Estuaries 17, 754-765.

Fogel M. L., Cifuentes L. A., Velinsky D. J., and Sharp J. H. (1992) Relationship of carbon availability in estuarine phytoplankton to isotopic composition. Mar. Ecol. Prog. Ser. 82, 291-300.

Ganeshram R. S., Pedersen T. F., Calvert S. E., McNeill G. W., and Fontugne M. R. (2000) Glacial-interglacial variability in denitrification in the world's oceans; causes and consequences. Paleoceanography 15, 361-376.

Goñi M. A., Ruttenberg K. C., and Eglinton T. I. (1997) Sources and contributions of terrigenous organic carbon to surface sediments in the Gulf of Mexico. Nature 389, 275-278.

Haddad R. I. and Martens C. S. (1987) Biogeochemical cycling in an organic-rich coastal marine basin; 9 , sources and accumulation rates of vascular plant-derived organic material. Geochim. Cosmochim. Acta 51, 2991-3001. 
Harding L. W. Jr. and Perry E. S. (1997) Long-term increase of phytoplankton biomass in Chesapeake Bay, 1950-1994. Mar. Ecol. Prog. Ser. 157, 39-52.

Hofmann M., Wolf-Gladrow D. A., Takahashi T., Sutherland S. C., Six K. D., and Maier-Reimer E. (2000) Stable carbon isotope distribution of particulate organic matter in the ocean: A model study. Mar. Chem. 72, 131-150.

Horrigan S. G., Montoya J. P., Nevins J. L., and McCarthy J. J. (1990) Natural isotopic composition of dissolved inorganic nitrogen in the Chesapeake Bay. Estuar. Coast. Shelf Sci. 30, 393-410.

Hughes M. K. and Diaz H. F. (1994) Was there a "Medieval Warm Period" and if so, where and when? Clim. Change 26, 109-142.

Hunt J. M. (1966) The significance of carbon isotope variations in marine sediment. In Advances in Organic Geochemistry: 2nd International Congress on Organic Geochemistry, pp. 27-36.

Ingram B. L., Conrad M. E., and Ingle J. C. (1996) Stable isotope and salinity systematics in estuarine waters and carbonates: San Francisco Bay. Geochim. Cosmochim. Acta 60, 455-467.

Karlsen A. W., Cronin T. M., Ishman S. E., Willard D. A., Holmes C. W., Marot M., and Kerhin R. (2000) Historical trends in Chesapeake Bay dissolved oxygen based on benthic Foraminifera from sediment cores. Estuaries 23, 488-508.

Keigwin L. D. (1996) The Little Ice Age and Medieval Warm Period in the Sargasso Sea. Science 274, 1504-1508.

Kemp W. M., Sampou P., Caffrey J., Mayer M., Henriksen K., and Boynton W. R. (1990) Ammonium recycling versus denitrification in Chesapeake Bay sediments. Limnol. Oceanogr. 35, 1545-1563.

Kemp W. M., Sampou P. A., Garber J., Tuttle J., and Boynton W. R. (1992) Seasonal depletion of oxygen from bottom waters of Chesapeake Bay: Roles of benthic and planktonic respiration and physical exchange processes. Mar. Ecol. Prog. Ser. 85, 137-152.

Kerhin R. T., Williams C., and Cronin T. M. (1998) Lithologic Descriptions of Piston Cores from Chesapeake Bay, Maryland. OpenFile Report, U.S. Geological Survey, OF 98-0787.

Langland M. J, Hainly R. A. (1997) Changes in Bottom SurfaceElevations in Three Reservoirs on the Lower Susquehanna River, Pennsylvania and Maryland, Following the January 1996 FloodImplications for Nutrient and Sediment Loads to Chesapeake Bay. USGS Water-Res. Invest. Report 97-4138.

Lehmann M. F., Bernasconi S. M., Barbieri A., and McKenzie J. A. (2002) Preservation of organic matter and alteration of its carbon and nitrogen isotope composition during simulated and in situ early sedimentary diagenesis. Geochim. Cosmochim. Acta 66, 3573-3584.

Liu K.-K. and Kaplan I. R. (1989) The eastern tropical Pacific as a source of ${ }^{15} \mathrm{~N}$-enriched seawater off southern California. Limnol. Oceanogr. 34, 820-830.

Lucotte M. (1989) Organic carbon isotope ratios and implications for the maximum turbidity zone of the St. Lawrence upper estuary. Estuar. Coast. Shelf Sci. 29, 293-304.

Malone T. C. (1991) River flow, phytoplankton production and oxygen depletion in Chesapeake Bay. Modern and Ancient Continental Shelf Anoxia. Geol. Soc. Spec. Pub. 58, 83-93.

Mann M. E. (2000) Lessons for a new millennium. Science 289, 253-254.

McArthur J. M., Tyson R. V., Thomson J., and Mattey D. (1992) Early diagenesis of marine organic matter: Alteration of the carbon isotopic composition. Mar. Geol. 105, 51-61.

McMillan C., Parker P. L., and Fry B. $(1980){ }^{13} \mathrm{C} /{ }^{12} \mathrm{C}$ ratios in seagrasses. Aquat. Bot. 9, 237-249.

Middelburg J. J. and Nieuwenhuize J. (1998) Carbon and nitrogen stable isotopes in suspended matter and sediments from the Schelde Estuary. Mar. Chem. 60, 217-225.
Miller C. V. (1992) Sedimentary Molybdenum; a Geochemical Indicator of Anoxia in Chesapeake Bay. Ph.D. dissertation, Department of Chemistry, University of Maryland-College Park.

Montoya J. P. (1994) Nitrogen isotope fractionation in the modern ocean: Implications for the sedimentary record. In Carbon Cycling in the Glacial Ocean: Constraints on the Ocean's Role in Global Change (eds. R. Zahn, T. F. Pedersen, M. A. Kaminski, and L. Labeyrie), pp. 259-279. Springer-Verlag, Berlin, Germany.

Montoya J. P., Horrigan S. G., and McCarthy J. J. (1990) Natural abundance of ${ }^{15} \mathrm{~N}$ in particulate nitrogen and zooplankton in the Chesapeake Bay. Mar. Ecol. Prog. Ser. 65, 35-61.

Montoya J. P., Horrigan S. G., and McCarthy J. J. (1991) Rapid, storm-induced changes in the natural abundance of ${ }^{15} \mathrm{~N}$ in a planktonic ecosystem, Chesapeake Bay, USA. Geochim. Cosmochim. Acta 55, 3627-3638

Officer C. B., Biggs R. B., Taft J. L., Cronin L. E., Tyler M. A., and Boynton W. R. (1984) Chesapeake Bay anoxia; origin, development, and significance. Science 223, 22-27.

Onstad G. D., Canfield D. E., Quay P. D., and Hedges J. I. (2000) Sources of particulate organic matter in rivers from the continental USA: Lignin phenol and stable carbon isotope compositions. Geochim. Cosmochim. Acta 64, 3539-3546.

Ostermann D. R. and Curry W. B. (2000) Calibration of stable isotopic data: An enriched $\delta^{18} \mathrm{O}$ standard used for source gas mixing detection and correction. Paleoceanography 15, 353-360.

Sachs J. P. and Repeta D. J. (1999) Oligotrophy and nitrogen fixation during eastern Mediterranean sapropel events. Science 286, 2485 2488.

Schubel J. R. (1968) Turbidity maximum of northern Chesapeake Bay. Science 161, 1013-1015.

Seliger H. H., Boggs J. A., and Biggley W. H. (1985) Catastrophic anoxia in the Chesapeake Bay in 1984. Science 228, 70-73.

Sigleo A. C. and Macko S. A. (1985) Stable isotope and amino acid composition of estuarine dissolved colloidal material. In Marine and Estuarine Geochemistry (eds. A. C. Sigleo and A. Hattori), pp. 29-46. Lewis.

Spiker E. C. (1980) The behavior of ${ }^{14} \mathrm{C}$ and ${ }^{13} \mathrm{C}$ in estuarine water: Effects of in situ $\mathrm{CO}_{2}$ production and atmospheric exchange. Radiocarbon 22, 647-654.

Stahle D. W., Cleaveland M. K., Blanton D. B., Therrell M. D., and Gay D. A. (1998) The lost colony and Jamestown droughts. Science 280, 564-567.

Stribling J. M. and Cornwell J. C. (1997) Identification of important primary producers in a Chesapeake Bay tidal creek system using stable isotopes of carbon and sulfur. Estuaries 20, 77-85.

Teranes J. L. and Bernasconi S. M. (2000) The record of nitrate utilization and productivity limitation provided by $\delta^{15} \mathrm{~N}$ values in lake organic matter-A study of sediment trap and core sediments from Baldeggersee, Switzerland. Limnol. Oceanogr. 45, 801-813.

Wada, E. (1980) Nitrogen isotope fractionation and its significance in biogeochemical processes occurring in marine environments. In Isotope Marine Chemistry (eds. E. Goldberg, Y. Horibe, and K. Saruhashi), pp. 375-398. Uchida Rokakuho.

Zimmerman A. R. and Canuel E. A. (2000) A geochemical record of eutrophication and anoxia in Chesapeake Bay sediments; anthropogenic influence on organic matter composition. Mar. Chem. 69, 117-137.

Zimmerman A. R. and Canuel E. A. (2002) Sediment geochemical records of eutrophication in the mesohaline Chesapeake Bay. Limnol. Oceanogr. 47, 1084-1093. 